
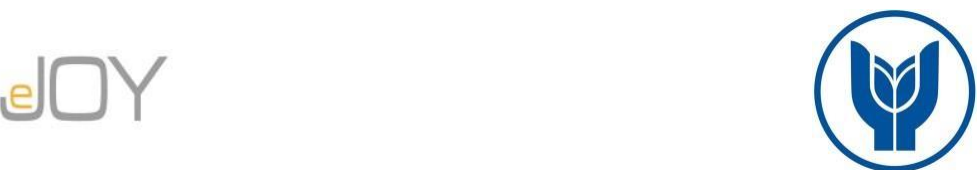

Durak Uşar, D., Aylak, B. L., Kayıkc1, Y. / Journal of Yasar University, 2021, 16/63, 1454-1479

\title{
Tedarik Zinciri Kademesinin ISO 9001 Kalite Yönetim Sertifikasyonu ve Finansal Performans İliş kisine Etkisi: Türkiye Örneği
}

\section{The Effect of Supply Chain Tier on the ISO 9001 Quality Management Certification and Financial Performance Relationship: The Case of Turkey}

\author{
Damla DURAK UŞAR, Türk-Alman Üniversitesi, Türkiye, damla.usar@tau.edu.tr \\ Orcid No: 0000-0001-8402-3856 \\ Batin Latif AYLAK, Türk-Alman Üniversitesi, Türkiye, batin.latif@tau.edu.tr \\ Orcid No: 0000-0003-0067-1835 \\ Yaşanur KAYIKCI, Türk-Alman Üniversitesi, Türkiye, yasanur@tau.edu.tr \\ Orcid No: 0000-0003-2406-3164
}

Öz: ISO 9001 Kalite Yönetim Sistemi belgesine sahip olmak günümüzde firmalar için önem arz etmektedir. Firmaların bütün kademelerinde olduğu gibi ISO 9001 belgesine sahip olmak tedarik zinciri kademesinde de çeşitli getiriler sağlamaktadır. Bu belge ile birlikte işletmeler daha iyi yönetilirken bir yandan da işletmelerin içinde bulunan bütün birimleri ilgilendiren süreçler için sürekli bir iyileştirme sağlanmaktadır. Işsletmelerin finansal performansı küresel rekabet ortamında işletmelerin başarılı olmaları için önemli bir göstergedir. Bu çalışmada BIST'e kote 165 adet üretim firmasından oluşan bir örneklem ile tedarik zinciri kademesinin, ISO 9001 Kalite Yönetim Sertifikasyonu ve finansal performans ilişkisine etkileri incelenmiştir. Firmalar tedarik zinciri kademelerine göre gruplandırlmış ve ISO 9001 belgesine sahip olmanın bu gruplardaki firmanın finansal performansına etkisi panel veri analizi yöntemi ile analiz edilmiştir. Çalışma sonucunda ISO 9001 kalite yönetim belgesine sahip olan firmaların bu belgeye sahip olmayan firmalara göre daha çok aktif karlılı̆̆a sahip oldukları tespit edilmiştir. Ancak tedarik zinciri kademesine göre bu ilişkiyi etkileyen farkl mekanizmaların olduğu saptanmıştır. Bulunan sonuçlar yöneticilere ISO 9001 belgesinin stratejik açıdan etkinliği konusunda rehberlik sağlamaktadır.

Anahtar Sözcükler: Toplam Kalite Yönetimi, ISO 9001 Kalite Yönetim Belgesi, Finansal Performans, Tedarik Zinciri Kademesi, Rekabet

JEL Siniflandirmast: C23, M11, L10, L60

\begin{abstract}
In today's competitive business environment, ISO 9001 Quality Management System certification has gained great importance for companies. ISO 9001 certification provides various benefits in different tiers in the supply chain as in different functions within the company. ISO 9001 certification enables continuous improvement for the processes that concern all units in the company, while businesses are better managed. The financial performance is an important indicator of business performance in a global competitive environment. In this study, the effect of supply chain tiers on ISO 9001 Quality Management System certification and the financial performance was analysed with a sample of 165 manufacturing companies listed on BIST from the multi-tier supply chain perspective. The companies were grouped according to their supply chain tiers and the effect of having ISO 9001 Quality Management System certification and the financial performance were analysed by panel data analysis method. The results indicate that certified companies outperform their uncertified counterparts financially. However, there are different mechanisms affecting the relationship between ISO 9001 Quality Management System certification and the financial performance according to different supply chain tiers. The results of this study provide guidance to managers in terms of strategic effectiveness of the ISO 9001 certificate.
\end{abstract}

\footnotetext{
Keywords: Total Quality Management, ISO 9001 Quality Management System Certification, Financial Performance, Supply Chain Tier, Competition
}

JEL Classification: C23, M11, L10, L60

Makale Gecmiși / Article History Başvuru Tarihi / Date of Application Kabul Tarihi / Acceptance Date
: 14 Kasım / November 2020

: 17 Mayıs / May 2021 


\section{Giriș}

Günümüz küresel ekonomisi karmaşık bir yapıya ve dinamik bir çevreye sahiptir. E-ticaret, sınır ötesi ticaret anlaşmaları, uluslararası seyahatin kolaylığg vb. ile birlikte yalnızca yerel operasyonları olan ve yalnızca yerel müşteri tabanlarına hizmet veren yerli firmaların sayısı giderek azalmaktadır. Günümüzde gerek küçük ölçekli gerek ise büyük ölçekli firmaların yabancı tedarikçi, ortak, çalışan, hissedar ve müşteri sayıları artmıştır (Caligiuri, 2006). Değişen pazar koşulları ile birlikte tedarik zincirinin her kademesinden firmaların rekabet üstünlüğü sağlamaları ve bu üstünlüğün sürdürülebilir olması için uluslararası kalite standartlarını tutturmaları önem taşımaktadır.

Dünyada en yaygın olarak kabul gören kalite standardı ISO 9001 kalite yönetim standardıdır. ISO 9001 kalite yönetim sisteminin firma performansı üzerine etkisi ampirik literatür incelemesi yapılarak araştırılmıştır. Kalite sertifikasının uygulamadaki firmaların içindeki entegrasyonunun farklı düzeyleri, firmaların finansal ve finansal olmayan performanslarını etkilemiştir (Duman, 2018). Uluslararası Standart Örgütü’ne göre, 2010 yılında dünya genelinde üretim firmalarının \%56's1 ISO 9001 kalite yönetim standardı kullanmaktadırlar. Türkiye'de ise bu oran 2010 yılında \%65'dir. Ancak 2018 yılına bakıldığında hem Türkiye'de hem de dünyada bu oran 46\%'ya düşmüştür ${ }^{1}$. Bu orandaki düşüş firmaların sertifikasyon sonucu bekledikleri olumlu finansal kazanımlara ulaşamadıkları anlamında yorumlanabilmektedir. Bu çalışmada ISO 9001 Kalite Yönetim Uygulaması ve Finansal Performans ilişkisini ampirik olarak ortaya koymak amaçlanmaktadır.

Küresel pazarda kalite yönetim sistemlerinin ürünün imalatından teslimatına kadar tedarik zinciri sistemlerinin içerisinde kullanımı yaygın bir hale gelmiştir (Flynn ve Flynn, 2005). Kalite yönetim uygulamalarının ISO 9001 belgesi şeklinde tedarik zincirlerinde kullanımı geçmişte araştırmacılar tarafından ortaya konulmuştur (Llach, Marimon, ve Bernardo, 2011; Franceschini vd., 2008; Corbett, 2008). Su, Kao, ve Linderman (2020) ISO 9001 belgesini tedarik zincirlerine entegre olarak kullanan firmalar için ISO 9001 belgesinin karlılığa olumlu etkisinin bu belgeyi tedarik zincirinden ayrı olarak kullanan firmalara göre daha fazla olduğu tespit etmişlerdir.

Literatüre göre ISO 9001 Kalite Yönetim Uygulaması ve Finansal Performans ilişkisi farklı kanallardan etkileyen başlıca mekanizmalar Kaynak Tabanlı Görüş (Wernerfelt, 1984) ve Paydaş Teorisine (Donaldson ve Preston, 1995; Berman vd., 1999) dayandırılabilir. ISO 9001

\footnotetext{
${ }^{1}$ ISO Content Server 2010-2018.

https://isotc.iso.org/livelink/livelink?func=1l\&objId=19931337\&objAction=browse\&viewType=1, erişim tarihi: 02/11/2020
} 
belgesinin bir kalite yönetim sistemi olarak firmaların süreçlerini optimize ettiği için firmalara rekabet avantajı sağladığı düşünülmüş ve ISO standartlarının şirketlerin iç verimliliğini iyileştirilmesiyle ilgili çeşitli çalışmalar yapılmıştır (Douglas ve Glen, 2000; Terziovski, Power, ve Sohal, 2003; Sharma, 2005, Heras-Saizarbitoria, 2011). Paydaş teorisine göre firmalar ISO 9001 sertifikasyon ile paydaşlarına kalitelerine dair bir sinyal vererek kurumsal itibarlarını artırarak rekabet avantajı sağlamaktadırlar. İlkay ve Aslan, (2012) işaret ettiği gibi sertifika bir pazarlama aracı gibi kullanılabilmektedir.

Bu çalışmada Türkiye'de üretim sektöründe faaliyet gösteren firmaların kalite yönetim uygulamalarının firmaların finansal performansa etkileri olup olmadığ 1 ekonometrik analizler sonucunda tespit edilmeye çalışılmıştır. Bu amaçla ISO 9001 sertifikasyonunun finansal performans üzerindeki etkileri ekonometrik bir model ile ortaya konmaktadır. 2010-2018 yılları arasında, BIST’e kote olmuş imalat firmalarının aktif kârlılık, öz kaynak verimliliği, kaldıraç oranı gibi finansal performans göstergeleri ve firmaların her y1l için ISO 9001 belgesine sahip olmaları derlenmiştir. Tespit edilen 165 imalat firmasının 2010-2018 yılları arasında ISO 9001 sertifikasyonu ile finansal performansları arasındaki ilişki detaylı olarak incelenmiştir.

Firma özelliklerinin ISO 9001 Kalite Yönetim Sertifikasyonu ve finansal performans ilişkisine etkisini kontrol etmek için firma büyüklüğü ve kaldıraç oranı analiz sırasında dikkate alınmıştır. Firmaların faaliyet gösterdikleri sektörün gerek finansal performanslarını gerekse ISO 9001 belgesini almalarını etkilemesinden dolayı, kontrol değişkeni olarak analizde yer verilmiştir. Firmaların içinde olduğu sektördeki rekabet seviyesinin de ISO 9001 belgesi alma kararını ve sertifikasyon- finansal performans ilişkisini etkileyeceği öngörülerek, sektördeki firmalar arasındaki ürün rekabetini ve sektördeki sertifikasyon rekabetini kontrol etmek için farklı kontrol değişkenleri oluşturulmuştur. Böylece rekabet gücünü etkileyen iki mekanizmanın ayrıştırılması amaçlanmıştır. Ürün rekabeti değişkeni ile kaynak tabanlı görüşün işaret ettiği ISO standartlarının şirketlerin iç verimliliğini iyileştirilmesi ile finansal performansa etkisi kontrol edilirken, sektördeki sertifikasyon rekabeti değişkeni ise Paydaş teorisinin işaret ettiği etkiyi kontrol etmektedir. Ayrıca firmaların farklı tedarik zinciri kademesinde olmalarının incelenen ilişkiye olan etkisi irdelenmiştir.

Çalışmanın literatüre katkısı üç ana başlık altında toplanabilir. Literatürdeki kalite alanındaki çalışmalardan farklı olarak rekabet, ürün pazarındaki rekabet ve sertifikasyon pazarındaki rekabet olmak üzere iki katmanlı olarak ele alınmıştır. Böylece ISO 9001 belgesine sahip olmanın itibar arttırıcı etkisi ve verimlilik artıııcı etkisi ayrıştırılmıştır. Firmaların farklı tedarik zinciri kademesinde olması da yapılan analiz analizlerde göz önünde bulundurulmuştur. $\mathrm{Bu}$ sayede sektör dinamikleri hem rekabet etkisi hem de tedarik zinciri etkisi dikkate alınarak 
bütüncül bakış açısı ile ele alınmıştır. Türkiye'de yapılan çalışmalar genel olarak vaka çalışmaları ve küçük veri setleri ile yapılmıştır. Bu çalışmada ise, BIST'e kote olan bütün üretim firmaları için sistematik veri toplanarak panel veri seti oluşturulmuştur. Bu şekilde istatiksel olarak güvenilir sonuçlar elde edilmiştir

Çalışmanın ikinci kısmında ISO 9001 kalite yönetim sistemi ve finansal performans ilişkisini inceleyen bir literatür taramasına yer verilmiştir. Bölüm 3'de ekonometrik model, veri seti ve analizde kullanılan değişkenler anlatılmıştır. Bölüm 4'de analiz sonuçları detaylı olarak tartışılmıştır. Bölüm 5'de teorik ve pratik çıkarımlar, çalışmanın kısıtları ve ileride yapılacak çalışmaları içeren sonuç bölümüne yer verilmiştir.

\section{Literatür}

Literatürde ISO 9001 sertifikasının kurumsal performans üzerindeki etkisini değerlendirmek için çeşitli çalışmalar yapılmıştır. Yapılmış çalışmalarda, sertifikasyonun ürün kalitesini, iş performansını, operasyonel performansı ve finansal performansı etkilediği tespit edilmiştir (Aba vd., 2016; Chen, Wu, ve Zhai, 2019; Corbett, Montes-Sancho, ve Kirsch, 2005; Javorcik ve Sawada, 2018; Turgut, 2014; Kutlu ve Duran, 2010; Sharma, 2005; Romano, 2000; İlkay ve Aslan, 2012; Kafetzopoulos, Psomas, ve Gotzamani, 2015; Sedani ve Lakhe, 2009).

$\mathrm{Bu}$ alandaki çalışmaların çoğu sertifikayı alan ve almayan şirketler arasında karşılaştırmalı analizlerden oluşmaktadır (Corbett, Montes-Sancho, ve Kirsch, 2005; Sharma, 2005; MartínezCosta ve Martínez-Lorente, 2007; Romano, 2000). Bu karşılaştırmalı çalışmalarda, sertifikasyonun kurumsal performans üzerindeki etkisi konusunda fikir birliği yoktur. Bazı çalışmalar sertifikasyonun şirket performansı üzerinde olumlu bir etkisi olduğunu gösterirken, bazı çalışmalar bunun olumsuz etkileri olduğunu ortaya koymuştur.

Corbett, Montes-Sancho, ve Kirsch (2005) ve Sharma (2005) boylamsal analiz ve finansal veriler kullanarak olumlu etkileri ortaya koymuşlardır. Sertifikasyonun finansal performans üzerindeki etkisini inceleyen araştırmasında Sharma (2005), sertifikalı şirketlerin sertifikalı olmayan şirketlerden daha iyi performans gösterdiğini bulmuştur. Finansal performans kriterleri olarak kâr marjı, satış büyümesi ve hisse başına kazancı kullanmıştır. (Corbett Montes-Sancho, ve Kirsch 2005), ilk ISO 9000 sertifikasını alma kararının finansal performansta bir iyileşme ile sonuçlandığını bulmuşlardır. Çalışmalarında sertifikasyondan üç yıl sonra, sertifikalı şirketlerin tüm kontrol grubu spesifikasyonlarında anormal bir performans gösterdiğini incelemişlerdir. Kontrol grubu özellikleri olarak aktif karlılık, satış kazancı, Tobins Q, COGS / SS, Satış kazancı ve satış kazancı / toplam varlık kullanmışlardır. ABD'de bir başka çalışma daha gerçekleştirilmiştir. Sertifikalı ve sertifikasız şirketleri karşılaştırırken Wilcoxon 
işaretli sıra testi kullanılmıştır. Bu analizde, vergi öncesi faaliyet karının toplam varlıklara oranı gibi çeşitli değişkenler incelenmiştir. Çalışma sonucunda, sertifikasyon yılında sertifikasyon öncesi yıla göre \%10’luk bir finansal iyileşme gözlenmiştir (Aba vd., 2016). Başka bir karşılaştırmalı çalışma Slovenya'da gerçekleştirilmiştir. Bu çalışmaya göre, ISO 9000 sertifikasına sahip şirketler, sertifikasyondan sonra satış, ihracat, kârlılık ve istihdam gibi çeşitli alanlarda olumlu etkilenmiştir (Javorcik ve Sawada, 2018).

$\mathrm{Bu}$ karşılaştırmalı çalışmalarda sertifikasyon öncesi ve sonrası süre önemlidir (Kafetzopoulos, Psomas, ve Gotzamani, 2015). Bu nedenle Romano (2000)'nun çalışması birçok kalite uzmanı tarafından eleştirilmiştir. (Romano, 2000) sertifikasyondan altı ay öncesi ve altı ay sonrası 100 İtalyan imalat şirketini incelemiştir. Performans ölçümlerinde iç ve dış kalite, kalite maliyetleri ve süreleri (üretim, teslimatın dakikliği, vb.) hesaba katılmış, sonuçlar şirketlerin iç kalitelerini ve üretim sürecinin güvenilirliğini geliştirdiklerini göstermiştir.

Sertifikalı ve sertifikasız şirketleri karşılaştıran bir çalışmada sertifikasyonun olumsuz etkileri olduğu bulunmuştur (Martínez-Costa ve Martínez-Lorente, 2007). Bu çalışmada panel verileri kullanılarak şirketlerin performansı, sertifikasyon öncesi üç yıl ve sertifikasyon sonrası üç yıl ile karşılaştırılmıştır. Sertifikalı şirketler sertifikasyondan önce sertifikalı olmayan şirketlerden daha iyi performans gösterirken, sertifikasyondan sonra sertifikalı olmayan şirketlerin gerisinde kaldıkları tespit edilmiştir. Bunun birkaç nedeni vardır. İlk neden, ISO 9000 sertifikasının maliyetli bir belge olmasıdır. Belgenin kaliteyi arttırdığı gösterilmiştir, ancak piyasa faydası standardının uygulanması ve bakımı belgenin maliyetini karşılamamaktadır. Ancak sonuçların genellenebilmesi ihtiyatla yapılmalıdır, çünkü bu araştırma çeşitli endüstrilerde ve sınırlı sayıda İspanyol şirket ile yapılmıştır. Bir başka çalışmada, ISO 9000 sertifikasının Çin'deki hizmet şirketlerinin finansal performansını olumsuz etkilediği gözlemlenmiştir. (Chen, Wu, ve Zhai, 2019) makalelerinde hem panel hem de anket verileri kullanmışlardır. Çalışmada satış, verimlilik ve karlılık açısından sertifikanın finansal etkisini incelemişlerdir. Verimlilik ve karlılık üzerinde olumsuz bir etki bulmuşlardır. Bununla birlikte, sertifikasyonun bir satış avantajı sunduğu, bu nedenle müşterilerin bu şirketi seçmeleri için bir sinyal aracı olarak gördüğünü bulmuşlardır. (Santos, Mendes, ve Barbosa, 2011) endüstri şirketlerinin ISO 9001 yatırımlarını diğer şirketlerden daha hızlı kazandıklarını bulmuşlardır. İmalat ve hizmet şirketlerinin \%72,73'ünün ISO 9001'deki yatırımlarını üç yıldan daha kısa bir sürede geri aldığını bulmuşlardır. Öte yandan, orta ölçekli şirketlerin ISO 9001 sertifikasyonundan sonraki üç yıl içinde ISO 9001 yatırımlarının karşılıklarını büyük şirketlerden daha hızlı aldıklarını tespit etmişlerdir. 
Buna ek olarak, Kafetzopoulos, Psomas, ve Gotzamani (2015) göre ISO 9001 sertifikas1 ürün kalitesi ve operasyonel performansta iyileşmeye yol açtığı için bir şirketi rakiplerinden ayırmaktadır. Bir imalat şirketinin rekabet avantajı elde edebilmesi için ISO 9001 hedeflerine ulaşma düzeyini artırmaya odaklanması gerekmektedir. ISO 9001 sertifikasının rekabet avantajı sağladığı sonucuna varılan bir başka çalışma (Sedani ve Lakhe, 2009) tarafından yapılmıştır. Bu çalışma kapsamında anket çalışması yöntemi ile Hindistan'da 250 sanayi şirketini incelemiştir. Sonuç olarak, katılımcıların \%22'sinin ISO 9000 serisi standartlarının rekabet avantajı sunduğunu ifade etmişlerdir. Ayrıca katılımcıların \%96'sının gelecekte ISO 9000 standardını kullanmak istediğini veya gelecekte kullanmak üzere kayıt olmak isteklerini dile getirmişlerdir.

Literatürde ISO 9001 standardının Türkiye'deki şirketlerin finansal performansını etkileyip etkilemediğine ilişkin araştırma sorusu ile ilgili çeşitli çalışmalar yapılmıştır. Çalışmaların çoğu vaka analizleri (Ayrıçay, Uğurlu, ve Uğurlu, 2009; Turgut, 2014; Özer ve Karabulut, 2017) veya yapılan anketlere dayanmaktadır (Eroğlu, 2004; İlkay ve Aslan, 2006; Aslanertik ve Tabak, 2006; Kutlu ve Duran, 2010; İlkay ve Aslan, 2012; Y1ldız ve Aytekin, 2019). Anket çalışmalarında sosyal istenirlik yanlılığı (Edwards, 1959) ve ortak yöntem yanlılığı (Sea-Jin, Witteloostuijn, ve Eden, 2010) gibi sonuçların güvenilirliğini tehlikeye atabilecek sıkıntılar oluşabilmektedir.

Kalite yönetim uygulamalarının şirketlerin finansal performansı üzerine etkisi olup olmadığı ve bu etkinin yönü ve düzeyi 4 adet çimento fabrikasında ampirik bir çalışma yapılarak gösterilmiştir. Ayrıçay, Uğurlu, ve Uğurlu, (2009) çalışmasında kalite yönetim uygulamalarının fabrikaların bazılarında finansal performansa olumlu bir katkı sağlarken bazılarında ise herhangi bir etki göstermediği gözlemlenmiştir. Özer ve Karabulut, (2017) kalite yönetim uygulamalarının işletme performansı üzerine etkisini inşaat sektöründeki 3 şirkette çalışan 300 kişi ile yaptıkları anket çalışması ile incelemişlerdir. Bu kapsamda performans dengeli başarı göstergesi boyutları yönünde finansal performansı da içeren 4 boyutta kolayda örnekleme yöntemi kullanılarak analiz edilmiştir. Yapılan analizler sonucunda kalite uygulamalarının işletmelerin performansını pozitif yönde etkilediği tespit edilmiştir. Turgut (2014), Piyasa Değeri ve Defter Değeri farkı olarak tanımlanan entelektüel sermaye üzerinde ISO 9001 kalite yönetim uygulamasının finansal bir etkisi olup olmadığını açıklamak amacıyla BIST’e kote olmuş üretim ve hizmet firmalarını incelemiştir. Çalışma 20 üretim şirketi ve 8 hizmet şirketi ile gerçekleştirilmiştir. Çalışmada sertifikasyondan önceki dört yıl ve sertifikasyondan sonraki dört yılı içeren dönem "Eşleştirilmiş T-Testi” ile analiz edilmiştir. Çalışma sonucunda anlamlı bir bulgu tespit edilememiştir. Yapılan çalışma nicel verilere 
dayansa da kullanılan örneklemin küçük olması nedeniyle elde edilen verilerin anlamlılık düzeyinin az olduğu düşünülmektedir. Her ne kadar vaka analizleri başarı öyküleri için ideal olsa da kalite sertifikasının performansı arttırdığını ortaya çıkartamamaktadırlar, sadece bunu yapabileceğini gösterebilmektedirler (Heras, Casadesús, ve Dick., 2002).

Aslan, İlkay, ve Özdemir (2009), kalite yönetim sistemi belgeli kuruluşların bu belgeye sahip olmayan kuruluşlara göre performanslarını karşılaştırılması amacıyla Kayseri'de bulunan KOBI'ler üzerine anket uygulamıştır. Anketin sonucunda performansların bazı kriterleri açısından önemli farklılıklar tespit edilmiştir. ISO 9001 belgesi firmaların finansal performansı, yenilik ve öğrenme performansları ile müşteri memnuniyeti kriterleri arasından bazılarının geliştirilmesinde etken bir rol oynamıştır. Adıgüzel ve Aydınlı (2016), ISO 9001 belgeli 92 adet bilişim firmalarında üst düzey yönetici olarak görev yapan 252 kişiden veriler toplayarak 9 adet hipotez geliştirmişlerdir. Daha sonra yapısal eşitlik modeli kullanılarak model değişkenleri arasında ilişkiler analiz edilerek ISO 9001 belgelerinin işletme performansı üzerine etkileri tespit edilmiştir. Yapılan analizler sonucunda ISO 9001 kalite yönetim sistemi uygulamalarının bilişim firmalarında işletme performansı üzerine pozitif etkilerinin olduğu tespit edilmiştir. İlkay ve Aslan (2012), ISO 9001 sertifikasının iş performansı üzerindeki etkisini belirlemek için 255 sertifikalı ve sertifikasız KOBİ’ye ilişkin bir anket gerçekleştirmişlerdir. Anket sonucunda ISO 9001 sertifikalı ve sertifikasız şirketler arasında istatistiksel olarak anlamlı bir fark bulunmamıştır. Finansal performans açısından ise, sertifikalı şirketlerin satış ve pazar payları iyileşmiştir. Bunun nedeni sertifikanın bir reklam ve satış aracı olarak kullanılması olduğu düşünülmüştür. Aslan, İlkay, ve Özdemir (2009), 111 tane ISO 9001 belgeli KOBİ’lerin verilerine tek yönlü varyans analizi yaparak danışmanlık hizmetinin performansa etkisi tespit etmişlerdir. Ayrıca sektörün kısmen etkisinin olduğu ve firmanın bulunduğu bölgenin sosyoekonomik gelişmişliği ve ne kadar süredir kalite belgesine sahip olduğunun ise herhangi bir etkisinin olmadığı tespit edilmiştir.

Yıldız ve Aytekin (2019), İstanbul Sanayi Odası'nın 2015'te ilk bin arasında ilan ettiği firmaların 203 tanesinden oluşan bir örneklem vasıtası ile firmaların performansı üzerinde inovasyon performansının rolünü incelemişlerdir. Bu çalışmada yapısal eşitlik modeli ile kalite yönetimi uygulamalarının firma performansına etkisi inovasyonun aracı rolü ve çevresel dinamizmin moderatör rolü dikkate alarak analiz edilmiştir. Yapılan analiz sonucunda toplam kalite yönetimi uygulamalarının inovasyon ve firma performansını pozitif yönde anlamlı olarak etkilediği tespit edilmiştir.

Özbuğday ve Tirgil (2020), Türkiye'de sanayi sektöründe faaliyet gösteren 654 firmada kalite yönetim uygulamalarının firmaların finansal performansı üzerine bir etkisi olup olmadığı 
araştırmışlardır. İncelenen etkinin ne yönde olacağı hakkında panel veri teknikleri ile analiz edilmiştir. Örneklemde bulunan firmalardan 342 firmanın kalite belgesine sahip olduğu saptanmıştır ve firmalar sertifikası olmayan firmalar ile birebir eşleştirilmiş ve aralarındaki farkl11ıklar ortaya konmuştur. Yapılan analizler sonucunda kalite yönetim uygulamalarının firmaların finansal performansları üzerine anlamlı olumlu bir etkiye sahip olmadı̆̆ tespit edilmiştir. ISO 9001 kalite yönetim standardını ve finansal performans ilişkisi inceleyen çalışmaların bir özeti Tablo 1'de gösterilmiş̧ir. 
Tablo 1. ISO 9001 Kalite Yönetim Standardı ve Finansal Performans İlişkisi İnceleyen Çalışmalar

\begin{tabular}{|c|c|c|c|c|c|c|}
\hline Araştırmacı & Örneklem & Zaman Aralı̆̆l & Bă̆ımlı Değişkenler & Bağımsız Değişkenler & Araştırma Metodu & Performansla İlişki \\
\hline Aba vd., 2016 & $\begin{array}{l}\text { ABD'de ISO } \\
\text { 9001 Sertifikalı } \\
397 \text { Şirket }\end{array}$ & $\begin{array}{l}\text { Panel Veri } \\
1991^{\prime} \text { den } \\
2002^{` y} \text { ye }\end{array}$ & $\begin{array}{c}\text { Finansal performans } \\
\text { Vergi Öncesi Faaliyet Kârının } \\
\text { Toplam Varlıklara Oranı }\end{array}$ & $\begin{array}{l}\text { ISO } 9001 \text { Sertifikası } \\
\text { Sahipliği }\end{array}$ & $\begin{array}{l}\text { Wilcoxon İşaret Sıra Testi, } \\
\text { Sertifikalı ve sertifikasız } \\
\text { şirketlerin karşılaştırılması }\end{array}$ & Olumlu \\
\hline $\begin{array}{l}\text { Adıgüzel ve } \\
\text { Aydınoğlu, } \\
2016\end{array}$ & $\begin{array}{l}\text { Türkiye'de } 92 \\
\text { Bilişim } \\
\text { Şirketinde } \\
\text { çalışan } 252 \text { kişi }\end{array}$ & $\begin{array}{l}\text { Kesit Veri } \\
\quad(\mathrm{y} 1 \mathrm{l} \\
\text { belirtilmemiş) }\end{array}$ & İşletme performans1 & $\begin{array}{c}\text { Anket Verileri } \\
\text { ISO } 9000 \text { Sertifikası } \\
\text { Sahipliği, Kalite } \\
\text { Yönetim Sistemleri } \\
\text { Prensipleri } \\
\end{array}$ & Yapısal eşitlik modeli & Olumlu \\
\hline $\begin{array}{l}\text { Aslan, İlkay, ve } \\
\text { Özdemir, } 2009\end{array}$ & $\begin{array}{l}\text { Türkiye'de } 111 \\
\text { adet Şirket }\end{array}$ & $\begin{array}{l}\text { Kesit Veri } \\
2006\end{array}$ & $\begin{array}{l}\text { Finansal Kriterler, Firma içi } \\
\text { kriterler, Müşteri Kriterleri, } \\
\text { Yenilik ve Öğrenme Kriterleri }\end{array}$ & $\begin{array}{c}\text { Anket Verileri } \\
\text { ISO 9000 Sertifikası } \\
\text { Sahipliği, sektör, } \\
\text { sosyo-ekonomik } \\
\text { gelişmişlik, sertifika } \\
\text { süresi }\end{array}$ & Tek yönlü varyans analizi & Olumlu \\
\hline $\begin{array}{c}\text { Ayriçay, } \\
\text { Uğurlu, ve } \\
\text { Uğurlu, } 2009\end{array}$ & $\begin{array}{l}\text { Türkiye'de } 4 \\
\text { adet Şirket }\end{array}$ & $\begin{array}{l}\text { Panel Veri } \\
1998-2007\end{array}$ & $\begin{array}{c}\text { Aktif karlılık, Satış karlılı̆̆ı, } \\
\text { Net kâr marjı, SMM/Net } \\
\text { Satışlar, (SMM + Faaliyet } \\
\text { Giderleri) / Net } \\
\text { Satışlar, Satışlardaki Büyüme }\end{array}$ & $\begin{array}{l}\text { ISO } 9001 \text { Sertifikası } \\
\text { Sahipliği }\end{array}$ & T-testi & Kısmi Olumlu Etki \\
\hline $\begin{array}{l}\text { Chen, } W u \text {, ve } \\
\text { Zhai, } 2019\end{array}$ & $\begin{array}{l}\text { Çin'de ISO } 9000 \\
\text { Sertifikalı } 6071 \\
\text { Hizmet Şirketi }\end{array}$ & $\begin{array}{l}\text { Panel Veri } \\
2005^{\prime} \text { den } \\
2008^{`} \mathrm{e}\end{array}$ & $\begin{array}{l}\text { Finansal performans } \\
\text { Satış, Verimlilik ve Kârlılık }\end{array}$ & $\begin{array}{l}\text { Anket Verileri } \\
\text { ISO } 9000 \text { Sertifikası } \\
\text { Sahipliği }\end{array}$ & $\begin{array}{c}\text { Eğilim Skoru Eşleme Analizi, } \\
\text { OLS Regresyonu }\end{array}$ & Olumsuz \\
\hline $\begin{array}{l}\text { Corbett } \\
\text { Montes- } \\
\text { Sancho, ve } \\
\text { Kirsch, } 2005\end{array}$ & $\begin{array}{l}\text { Amerika'da } 554 \\
\text { Üretim Şirketi }\end{array}$ & Panel Veri & $\begin{array}{c}\text { Verimlilik İyileştirmeleri, } \\
\text { Piyasa Avantajları ve Finansal } \\
\text { Performans aktif karlılık, satış } \\
\text { karlılığı, Tobin Q, COGS / } \\
\text { SALES, SALES ve SALES / } \\
\text { ASSETS }\end{array}$ & $\begin{array}{l}\text { ISO } 9000 \text { Sertifikası } \\
\text { Sahipliği } \\
\text { Sertifikasyon Öncesi } \\
3 \text { Y1l, Sertifikasyon } \\
\text { Sonras1 } 3 \text { Y1l }\end{array}$ & $\begin{array}{l}\text { Wilcoxon İşaret Sıra Testi, } \\
\text { Eşleştirme Yöntemi } \\
\text { Sertifikalı ve sertifikasız } \\
\text { şirketlerin karşılaştırılması }\end{array}$ & Olumlu \\
\hline
\end{tabular}


Durak Uşar, D., Aylak, B. L., Kayıkcı, Y. / Journal of Yasar University, 2021, 16/63, 1454-1479

\begin{tabular}{|c|c|c|c|c|c|c|}
\hline Araştırmacı & Örneklem & Zaman Aralı̆̆ & Bă̆ımlı Dĕgişkenler & Bă̆ımsız Değişkenler & Araştırma Metodu & Performansla İlişki \\
\hline $\begin{array}{l}\text { Ilkay ve Aslan, } \\
2006\end{array}$ & $\begin{array}{l}\text { Türkiye'de } 39 \\
\text { şirket }\end{array}$ & $\begin{array}{l}\text { Kesit Veri } \\
2005\end{array}$ & İşletme performansı & $\begin{array}{c}\text { Anket Verileri } \\
\text { ISO 9001 Sertifikası } \\
\text { Sahipliği } \\
\end{array}$ & Yapısal eşitlik modeli & Olumlu \\
\hline $\begin{array}{l}\text { Ilkay ve Aslan, } \\
2012\end{array}$ & $\begin{array}{l}\text { Türkiye'de } 255 \\
\text { Küçük ve Orta } \\
\text { Ölçekli İşletme } \\
\text { (KOBİ) }\end{array}$ & $\begin{array}{l}\text { Kesit Veri } \\
\quad(\mathrm{y} 1 \mathrm{l} \\
\text { belirtilmemiş) }\end{array}$ & $\begin{array}{l}\text { Finansal Performans } \\
\text { İş Performansı }\end{array}$ & $\begin{array}{l}\text { Anket Verileri } \\
\text { ISO } 9000 \text { Sertifikası } \\
\text { Sahipliği }\end{array}$ & $\begin{array}{l}\text { Tek Yönlü Varyans Analizi } \\
\text { (Tek Yönlü ANOVA) }\end{array}$ & $\begin{array}{l}\text { Finansal } \\
\text { Performans Olumlu, } \\
\text { İş Performans1 Nötr }\end{array}$ \\
\hline $\begin{array}{l}\text { Javorcik ve } \\
\text { Sawada, } 2018\end{array}$ & $\begin{array}{l}\text { Slovenya'da ISO } \\
9000 \text { Sertifikalı } \\
668 \text { Şirket }\end{array}$ & $\begin{array}{l}\text { Panel Veri } \\
\text { 1987'den } \\
2006^{`} \text { ya }\end{array}$ & $\begin{array}{l}\text { Operasyonel ve Finansal } \\
\text { Performans } \\
\text { Satış, İhracat ve İstihdam. }\end{array}$ & $\begin{array}{l}\text { ISO } 9001 \text { Sertifikası } \\
\text { Sahipliği, } \\
\text { Sertifikasyon Öncesi } \\
\text { ve Sonrası } 3 \text { Y1l }\end{array}$ & $\begin{array}{l}\text { OLS-Regresyon Ekonometrik } \\
\text { Analizi }\end{array}$ & Olumlu \\
\hline $\begin{array}{l}\text { Kafetzopoulos, } \\
\text { Psomas, ve } \\
\text { Gotzamani, } \\
2015\end{array}$ & $\begin{array}{l}\text { Yunanistan'da } \\
\text { ISO 9001 } \\
\text { Sertifikalı } 287 \\
\text { Üretim Şirketi } \\
\end{array}$ & $\begin{array}{l}\text { Kesit Veri } \\
\text { (yıl } \\
\text { belirtilmemiş) }\end{array}$ & $\begin{array}{l}\text { Ürün Kalitesi, Operasyonel } \\
\text { Performans ve İş Performansı }\end{array}$ & $\begin{array}{c}\text { Anket Verileri } \\
\text { ISO } 9001 \text { Sertifikası } \\
\text { Sahipliği, İşletme } \\
\text { Performansı } \\
\end{array}$ & $\begin{array}{c}\text { Açıklayıcı Faktör Analizi } \\
\text { (EFA), Doğrulama Faktör } \\
\text { Analizi (CFA), Yapısal Eşitlik } \\
\text { Modellemesi (SEM) }\end{array}$ & Olumlu \\
\hline $\begin{array}{l}\text { Martínez-Costa } \\
\text { ve Martinez- } \\
\text { Lorente, } 2007\end{array}$ & $\begin{array}{c}\text { İspanya'da } 217 \\
\text { Üretim Şirketi }\end{array}$ & $\begin{array}{l}\text { Kesit Veri } \\
\quad \text { (yıl } \\
\text { belirtilmemiş) }\end{array}$ & $\begin{array}{c}\text { Finansal Performans, Kâr ve } \\
\text { aktif karlılık }\end{array}$ & $\begin{array}{c}\text { Anket Verileri } \\
\text { ISO } 9000 \text { Sertifikası } \\
\text { Sahipliği }\end{array}$ & $\begin{array}{c}\text { T-Test } \\
\text { Sign Test }\end{array}$ & Olumsuz \\
\hline $\begin{array}{l}\text { Özbuğday ve } \\
\text { Tirgil, } 2020\end{array}$ & $\begin{array}{c}\text { Türkiye' de } 652 \\
\text { Üretim Şirketi }\end{array}$ & $\begin{array}{l}\text { Panel Veri } \\
2009-2013\end{array}$ & Satış büyüme oranı & $\begin{array}{l}\text { ISO } 9000 \text { Sertifikası } \\
\text { Sahipliği }\end{array}$ & $\begin{array}{c}\text { Entropi dengelemesi ile } \\
\text { eşleştirme yöntemi ile Sertifikalı } \\
\text { ve sertifikasız şirketlerin } \\
\text { karşılaştırılması }\end{array}$ & $\begin{array}{c}\text { Anlamlı etki } \\
\text { bulunamamıştır }\end{array}$ \\
\hline $\begin{array}{l}\text { Özer ve } \\
\text { Karabulut, } \\
2017\end{array}$ & $\begin{array}{c}\text { Türkiye'de } \\
\text { çalışan } 300 \text { kişi }\end{array}$ & $\begin{array}{c}\text { Kesit Veri } \\
\text { (yıl } \\
\text { belirtilmemiş) }\end{array}$ & $\begin{array}{c}\text { Finansal Performans ve İş } \\
\text { Performansı }\end{array}$ & $\begin{array}{c}\text { Anket Verileri } \\
\text { Kalite Uygulamaları }\end{array}$ & $\begin{array}{c}\text { Faktör Analizi, Korelasyon } \\
\text { Analizi, Çoklu regresyon analizi }\end{array}$ & Olumlu \\
\hline $\begin{array}{c}\text { Yildiz ve } \\
\text { Aytekin, } 2019\end{array}$ & $\begin{array}{l}\text { Türkiye'de } 203 \\
\text { adet Şirket }\end{array}$ & $\begin{array}{l}\text { Kesit Veri } \\
\quad 2017\end{array}$ & Firma Performans1 & $\begin{array}{c}\text { Anket Verileri } \\
\text { Toplam Kalite } \\
\text { Yönetimi } \\
\text { Uygulamaları, } \\
\text { Çevresel Dinamizm } \\
\text { moderatör etkisi, } \\
\text { İnovasyon } \\
\text { Performansının aracı } \\
\text { etkisi }\end{array}$ & $\begin{array}{c}\text { Keşfedici Faktör Analizi (KFA) } \\
\text {, Doğrulayıcı Faktör Analizi } \\
\text { (DFA), Yapısal eşitlik modeli }\end{array}$ & Olumlu \\
\hline
\end{tabular}


Durak Uşar, D., Aylak, B. L., Kayıkcı, Y. / Journal of Yasar University, 2021, 16/63, 1454-1479

\begin{tabular}{|c|c|c|c|c|c|c|}
\hline Araştırmacı & Örneklem & Zaman Aralı̆̆ & Bă̆ımlı Değişkenler & Bağımsız Değişkenler & Araştırma Metodu & Performansla İlişki \\
\hline Romano, 2000 & $\begin{array}{l}\text { İtalya'da } 100 \\
\text { Üretim Şirketi }\end{array}$ & $\begin{array}{l}1993 \text { 'ten } \\
1995^{\prime} \mathrm{e}\end{array}$ & $\begin{array}{c}\text { Operasyonel ve Finansal } \\
\text { Performans }\end{array}$ & $\begin{array}{c}\text { Anket Verileri } \\
\text { ISO } 9000 \\
\text { Sertifikasyon } \\
\text { Sahipliği, } \\
\text { Sertifikasyon } \\
\text { Süresinin Etkileri }\end{array}$ & $\begin{array}{c}\text { Parametrik olmayan analiz } \\
\text { Kruskal Wallis testi }\end{array}$ & Olumlu \\
\hline Sharma, 2005 & $\begin{array}{c}\text { Singapur } \\
\text { Menkul } \\
\text { Kiymetler } \\
\text { Borsası'nda } \\
\text { İşlem Gören } 70 \\
\text { Şirket }\end{array}$ & $\begin{array}{l}\text { Panel Veri } \\
6 \text { yıllık bir } \\
\text { zaman aralığı } \\
\text { incelenmiştir. }\end{array}$ & Finansal Performans, & $\begin{array}{c}\text { GSALES = } 3 \text { Yıllık } \\
\text { Satış Büyümesi } \\
\text { EPS = Vergi Sonrası } \\
\text { Faaliyet Kârının İhraç } \\
\text { Edilen İmtiyazlı } \\
\text { Hisselere Bölünmesi } \\
\text { PM = Faiz, Vergi ve } \\
\text { Olağanüstü Kalem } \\
\text { Öncesi Kazançların } \\
\text { Net Satışlara Bölümü }\end{array}$ & $\begin{array}{l}\text { Çok değişkenli analiz } \\
\text { Duyarlılık analizi } \\
\text { Sertifikalı ve sertifikasız } \\
\text { şirketlerin karşılaştırılması }\end{array}$ & Olumlu \\
\hline Turgut, 2014 & $\begin{array}{l}\text { Borsa İstanbul'a } \\
\text { Kote Olmuş } 28 \\
\text { Firma }\end{array}$ & $\begin{array}{l}\text { Panel Veri } \\
8 \text { yıllık bir } \\
\text { zaman aralığı } \\
\text { incelenmiştir. }\end{array}$ & $\begin{array}{c}\text { Entelektüel Sermaye } \\
\text { Piyasa değeri / Defter değeri }\end{array}$ & $\begin{array}{l}\text { ISO } 9001 \text { Sertifikası } \\
\text { Sahipliği, } \\
\text { Sertifikasyon Öncesi } \\
\text { ve Sonrası } 4 \text { Yıl }\end{array}$ & $\begin{array}{l}\text { Eşlenik Grup Testi } \\
\text { Eşleştirilmiş Gruplar için T- } \\
\text { Testi }\end{array}$ & Olumsuz \\
\hline
\end{tabular}




\section{Ekonometrik Model}

$\mathrm{Bu}$ çalışmanın amacı, ISO 9001 kalite yönetim standardının finansal bir gösterge olan firmaların yatırım getirisi yani aktif karlılık üzerindeki etkilerini incelemek ve literatüre katkı sağlamaktır. Bu hedef doğrultusunda ISO 9001 ile aktif karlılık değerleri arasındaki ilişki çeşitli analizlerle test edilmelidir. Bu nedenle BIST'e kote olan 165 imalatçı firma 2010-2018 yılları arasında incelenmiştir. Şekil 1'de Ekonometrik modelin geliştirilmesinde kullanılan iş akışı diyagramı verilmiştir.

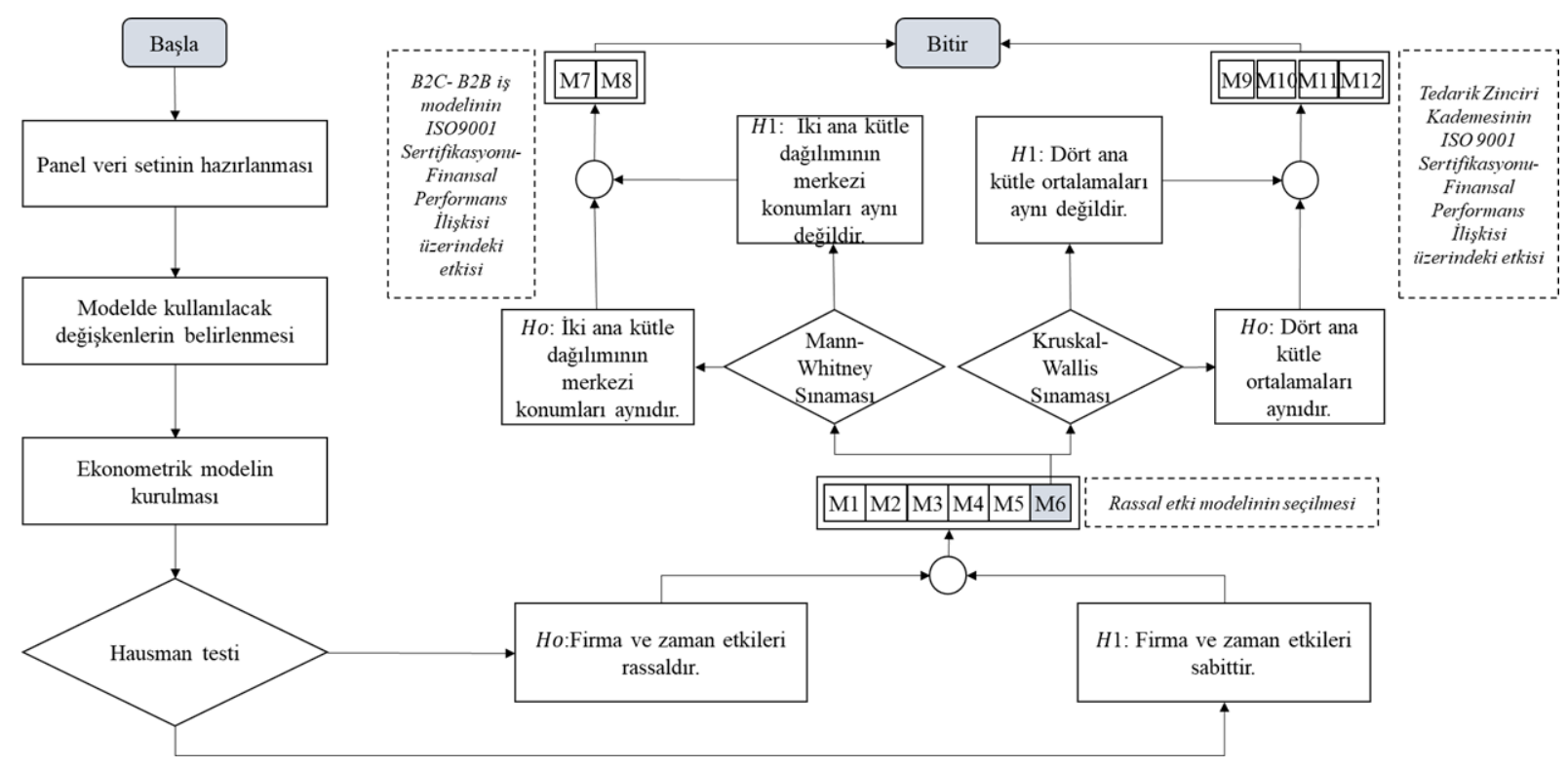

Şekil 1. Ekonometrik modelin geliştirilmesinde kullanılan iş akışı diyagramı

\subsection{Veri Seti}

BIST'e kote olan 224 üretim şirketinin verilerine Wharton Research Data Services COMPUSTAT veri seti aracılığıyla ulaşılmıştır. BIST’e kote olan ve 2010-2018 yı1ları arasında her yıl aktif olan imalat firmaları saptanmıştır. Veri setinin dengeli olmasını sağlamak için 59 üretim şirketi yani veri setinin \%26,33'ü veri setinden çıkarılmıştır. 2010'dan 2018'e kadar her y1l verileri bulunan şirketler incelenmiş ve tespit edilen 165 firmanın 9 yıl boyunca bilgileri derlenerek bir panel veri seti oluşturulmuştur.

Ortak yöntem yanlılığı, araştırma sonuçlarının geçerliliğini tehlikeye atabilecek ciddi ve sorunlu bir konudur. Değişkenler arasında bir korelasyon oluşturur ve tahmin edilen ilişkinin yanlış tahmin edilmesine yol açabilir. Ortak yöntem yanlılığından kaçınmak için, mümkün olduğunca farklı kaynaklardan gelen bilgilerden bağımlı ve bağımsız değişkenler oluşturmak önemli bir çözüm olacaktır. (Sea-Jin Chang vd., 2010). Bu nedenle, bu çalışmada veri seti oluştururken çeşitli kaynaklar kullanılmıştır. 
Toplam Varlıklar, Toplam Uzun Vadeli Borçlar, Faiz ve Vergi Öncesi Kazanç, Çalışan Sayıs1, Toplam Cari Borçlar, Toplam Borç, Toplam Varlıklar, Toplam Öz sermaye, Ar-Ge Giderleri, Net Gelir, Toplam Satışlar gibi firmaya özgü veriler Wharton Research Data Services COMPUSTAT'tan indirilmiştir. Ayrıca şirketlerin temel faaliyet alanlarını özetleyen iki basamaklı Standart Industry Classification (SIC) kodları da Wharton Research Data Services COMPUSTAT’tan indirilmiştir.

Firmaların 2010-2018 yılları için ISO 9001 belgesine sahip olup olmadıkları Kamuyu Aydınlatma Platformu (KAP) aracılığıyla ve resmi internet sitelerinde yer alan yıllık raporlar taranarak derlenmiştir. Ayrıca firmaların tedarik zinciri kademeleri, yani işletmeden tüketiciye veya işletmeden işletmeye ticaret yapma durumları KAP aracılığıyla ve resmi internet sitelerinde yer alan yıllık raporlar taranarak derlenmiştir.

Firmalar, SIC kodlarının yardımı ile KAP tarafından tanımlanan sektörlere ${ }^{2}$ göre gruplandırılmıştır. Tablo 2'de firmaların sektörlere göre dağılımı verilmiştir. Tablo 2'den görülebileceği gibi veri setinde en yüksek oran Metal Eşya, Makine, Elektrikli Cihazlar ve Ulaşım Araçları sektörüne aittir. İncelenen her 5 firmadan 1'i bu sektöründe faaliyet göstermektedir. Orman ürünleri ve mobilya ürünlerini içeren sektör ise 3 firma ile veri setinde en düşük paya sahip sektörü göstermektedir.

Tablo 2. Firmaların Sektörlere göre Dağılımı

\begin{tabular}{|l|l|c|c|}
\hline \multirow{2}{*}{ Sektör } & SIC Kodlarl & \multicolumn{2}{|c|}{ N=165 } \\
\cline { 2 - 4 } & & 27 & 16,36 \\
\hline Gıda, İçecek ve Tütün & 20,21 & 23 & 13,94 \\
\hline $\begin{array}{l}\text { Tekstil, Giyim Eşyası ve } \\
\text { Deri }\end{array}$ & $22,23,31$ & 3 & 1,81 \\
\hline $\begin{array}{l}\text { Orman Ürünleri ve } \\
\text { Mobilya }\end{array}$ & 24,25 & 12 & 7,27 \\
\hline $\begin{array}{l}\text { Kâğt ve Kâğı Ürünleri, } \\
\text { Basım ve Yayın }\end{array}$ & 26,27 & 25 & 15,15 \\
\hline $\begin{array}{l}\text { Kimya, İlaç, Petrol, } \\
\text { Lastik ve Plastik Ürünler }\end{array}$ & $28,29,30$ & 24 & 14,55 \\
\hline Taşve Toprăga Dayalı & 32 & 11 & 6,67 \\
\hline Ana Metal Sanayi & 33 & 35 & 21,21 \\
\hline $\begin{array}{l}\text { Metal Eşya, Makine, } \\
\text { Elektrikli Cihazlar ve } \\
\text { Ulaşım Araçlart }\end{array}$ & $34,35,36,37,38$ & & 3,03 \\
\hline Diğer İmalat Sanayi & 39 & 5 & \\
\hline
\end{tabular}

\footnotetext{
${ }^{2}$ https://www.kap.org.tr/tr/Sektorler Erişim tarihi: 02/11/2020
} 


\subsection{Değişkenler}

Bu çalışmada ISO 9001 kalite yönetim standardının aktif karlılık üzerindeki etkisini ortaya konması amaçlandığı için bağımlı değişken olarak "aktif karlılık” saptanmıştır. Aktif karlılık firmanın net gelirinin toplam varlığına bölünmesi ile hesaplanmıştır.

Bağımsız değişken olarak firmanın ISO 9001 kalite yönetim belgesine sahip olması saptanmıştır. Bu sebep ile "ISO 9001” kukla değişkeni oluşturulmuştur. Firmanın incelenen yılda sertifikasyonu var ise kukla değişkene 1 değeri atanmıştır, eğer o yıl için sertifikasyon yok ise 0 değeri atanmıştır.

Kontrol değişkenleri iki ana grupta toplanmıştır. ISO 9001 sertifikasyonu alma kararını ve finansal performansı etkileyebilecek firmaya özgü faktörler ve pazar faktörleri dikkate alınmıştır. Firma büyüklüğü finansal performansı etkileyebilen bir faktördür, ayrıca büyük firmaların ISO 9001 sertifikasyonu için yatırım yapacak finansal güce sahip oldukları için bu sertifikasyonu alma ihtimalleri daha yüksektir. Hem bağımlı hem de bağımsız değişken üzerinde etkisi olabileceği düşünüldüğü için “firma büyüklüğü” analize katılmıştır. Firma büyüklüğü asimetrik dağılım gösterdiği için toplam varlıkların doğal logaritması alınarak hesaplanmıştır.

Firmaların aktif karlılığını etkileyecek firmaya özgü başka bir değişken "kaldıraç oranıdır". Kaldıraç oranı bir şirketteki varlıkların ne kadarının borçlar ile finanse edildiğini gösterir. Kaldıraç oranı firmanın toplam borcunun toplam varlığına bölünmesi ile hesaplanmıştır.

Firmaya özgü bir başka kontrol değişkeni ise firmanın faaliyet gösterdiği sektördür. Analize sektör kontrolleri ilave edilerek farklı sektördeki firmaların karşılaştırılmasının ve dışlanmış değişken yanlılığının oluşmasının engellenmesi amaçlanmıştır.

Tablo 3. Betimsel Bulguları

\begin{tabular}{|l|c|c|c|}
\hline Değişken & $\begin{array}{c}\text { Gözlem } \\
\text { Sayıs }\end{array}$ & $\begin{array}{c}\text { Ortalam } \\
a\end{array}$ & $\begin{array}{c}\text { Standart } \\
\text { Sapma }\end{array}$ \\
\hline Aktif Karlılık (\%) & 1485 & 3,091609 & 9,97014 \\
\hline $\begin{array}{l}\text { Toplam Varlıklar (milyon } \\
\text { TL) }\end{array}$ & 1485 & 1464,527 & 3934,302 \\
\hline Net Gelir (milyon TL) & 1485 & 82,68525 & 324,0761 \\
\hline Kaldıraç Oranı (\%) & 1485 & 0,497918 & 0,244156 \\
\hline Çalışan Sayısı (1000 kişi) & 1485 & 1,125135 & 3,428368 \\
\hline Pazar Payı & 1485 & 0,054546 & 0,112835 \\
\hline
\end{tabular}

ISO 9001 sertifikasyonu ve finansal performans ilişkisinde firma karakteristiklerinin yanı sıra pazar karakteristiklerin de etkili olacağı beklenmektedir. Bu sebep ile iki farklı kontrol değişkeni oluşturulmuştur. Bir sektördeki çok sayıda firma olması ve çetin bir rekabet ortamının 
olmasının hem firmaların finansal performansını hem de ISO 9001 sertifikasyonu almalarını etkileyeceği öngörülmektedir. Firmaların rekabet güçlerini olumlu etkileyeceği beklentisi ile ISO 9001 sertifikasyonu alma ihtimallerini arttırması beklenmektedir. Pazardaki rekabetin her firma üzerindeki etkisini ölçmek için "pazar konsantrasyonu” değişkeni oluşturulmuştur. Pazar konsantrasyonu değişkeni oluşturmak için her firma için Zwanziger, Melnick, ve Simonson, (1996) tarafından geliştirilen ağırlıklı Herfindahl-Hirschman Index (HHI) hesaplanmıştır. Bu hesaplama 2 kademeden oluşmaktadır. İlk kademede her sektör için firmaların pazar paylarının karelerinin toplamı hesaplanarak HHI oluşturulmuştur. İkinci kademede her firma için kendi pazar payları ile ağırlıklandırılarak, ağırlıklı HHI hesaplanmıştır.

Sektörde faaliyet gösteren firma sayısı ve pazar paylarından bağımsız olarak bir sektörde ISO 9001 sertifikasyonu alan firma sayısının artmasının, o sektörde faaliyet gösteren diğer firmaların ISO 9001 sertifikasyonu alma ihtimallerini etkileyebilir. Sektörde belli başlı oyuncuların sertifikasyon alması ile sertifikasyonun sektör standardı haline gelmesi ve firmaları rekabet güçlerini korumak için sertifikasyon alma yoluna gitmesi beklenmektedir. Bu sebep ile "pazar sertifikasyon konsantrasyonu” değişkeni oluşturulmuştur. Bu değişken odaktaki firma haricinde sektörde faaliyet gösteren sertifikasyonlu firmaların tüm firmalara oranı hesaplanarak oluşturulmuştur. Tablo 3'de veri saatine dair betimsel istatistikler sunulmuştur.

\subsection{Ekonometrik Model}

Çalışmanın veri seti 165 imalatçı firma için 9 yıllık finansal bilgileri içermektedir ve çok yönlü bir veri setidir. Bu tür ekonometrik çalışmalarda genellikle panel veri analizinin kullanıldığ görülmektedir. Panel veri analizi, zaman serisi verileri ile yatay kesit verilerinin birleştirilmesiyle gerçekleştirilen analizdir. $\mathrm{Bu}$ çalışmada firmalara özgü etkilerin gözlemlenmesi amaçlandığı için rassal etki modeli seçilmiştir ve aşağıda verilen denklem [1] ile ifade edilmektedir (Baltagi, 2005). $\mathrm{Bu}$ seçim Hausman spesifikasyon testi ile desteklenmiştir.

$Y_{i t}=\left(a+\mu_{i}+\lambda_{i t}\right)+\beta_{1 i t} X_{1 i t}+\beta_{2 i t} X_{2 i t}+\cdots+\beta_{m i t} X_{m i t}+u_{i t} \quad i=1,2, \ldots N ; t=1,2, \ldots T$

$i=$ gözlemlenen birim

$t=$ zaman

$Y_{i t}:$ bă̆

$a+\mu_{i}+\lambda_{i t}:$ sabit

$X_{\text {mit }}:$ bağımsız de ğişkenler

$\beta_{\text {mit }}$ : bağımsız değişkenler için katsayı

$u_{i t}:$ hata terimi 


\subsection{Hausman Testi}

Birim veya birim ve zaman farklılıklarını temsil eden katsayıların yani tesadüfi etkili modelin hata terimi bileşenlerinin modeldeki bağımsız değişkenlerden ilişkisiz olduğu hipotezinin geçerliliği, Hausman (1978) tarafından önerilen test istatistiği ile incelenebilmektedir. Hausman test istatistiği "Rassal etkiler tahmincisi doğrudur" sıfır hipotezi altında k-1 serbestlik dereceli ki-kare $\left(\mathrm{chi}^{2}\right)$ dağılımı göstermektedir (Greene, 2011). Hausman testinin sonucunda (Prob > chi2) $>0,05$ ise, model bir rassal etki modeli olarak kabul edilir. Ancak (Prob > chi2) $<0,05$ ise, model sabit etki modeli olarak kabul edilir (Das, 2015). Tablo 4'te görülebileceği gibi (Prob > chi2) $=0,0627>0,05$ olarak gözlenmiştir. Bu neden ile rassal etki modelinin kullanılması kararı desteklenmiştir ve Bölüm 4'de analizler rassal etki modeline göre yapılmıştır.

Tablo 4. Hausman Testi

\begin{tabular}{|c|c|c|c|c|}
\hline & $\begin{array}{l}\text { (b) } \\
\text { Sabit Etkiler } \\
\text { Tahmini }\end{array}$ & $\begin{array}{l}\text { (B) } \\
\text { Rassal Etkiler } \\
\text { Tahmini }\end{array}$ & $\begin{array}{l}\text { (b-B) } \\
\text { Fark }\end{array}$ & $\begin{array}{l}\operatorname{sqrt}\left(\operatorname{diag}\left(\mathrm{V}_{-} \mathrm{b}-\right.\right. \\
\left.\left.\mathrm{V} \_\mathrm{B}\right)\right) \\
\text { S.E. }\end{array}$ \\
\hline ISO 9001 & 1,258481 & 1,743684 & $-0,4852$ & 0,407995 \\
\hline Firma büyüklüğü & 1,719049 & 1,221312 & 0,497737 & 0,3045233 \\
\hline Kaldıraç oranı & $-20,20526$ & $-18,86342$ & $-1,34184$ & 0,7291933 \\
\hline Pazar konsantrasyonu & $-7,712432$ & $-1,69541$ & $-6,01702$ & 2,66278 \\
\hline Pazar sertifikasyon & & & & \\
\hline konsantrasyonu & 9,383984 & 10,00305 & $-0,61906$ & 1,125533 \\
\hline & \multicolumn{4}{|c|}{$\begin{array}{l}\mathrm{b}=H o \text { ve } H 1 \text { altında tutarl } \\
\mathrm{B}=H 1 \text { altında tutarsiz, } H o \text { altında } \\
\text { etkin }\end{array}$} \\
\hline & \multicolumn{4}{|c|}{$\begin{array}{l}\text { Test: } H o \text { katsayılar arasındaki farklar sistematik değildir } \\
\text { chi }^{2}(5)=(\text { b-B })^{\prime}\left[\left(V_{-} \text {b-V_B }\right)^{\wedge}(-1)\right](b-B)= \\
10.48\end{array}$} \\
\hline & \multicolumn{4}{|c|}{ Prob > chi ${ }^{2}=0,0627$} \\
\hline
\end{tabular}

\section{Analiz Sonuçları}

Tablo 5'te sunulan tüm modellerde bağımlı değişken finansal performansın göstergesi olan aktif karlılık değeri iken bağımsız değişken ISO 9001 sertifikasına sahip olmasıdır. ISO 9001 sertifikasına sahip olma ISO 9001 kukla değişkeni ile temsil edilmiştir. İleriye doğru seçim yönteminde, her defasında bir bağımsız değişken ilave edilerek en uygun regresyon modelinin bulunması hedeflenmiştir (Alpar, 2003). Model 1'de sadece bir bağımsız değişken ile regresyon yapılmıştır. Model 2'de sertifikasyonun aktif karlılık üzerinde etkisi endüstri için kontrol değişkenleri kullanılarak tahmin edilmiştir. Model 3'de sertifikasyonun aktif karlılık üzerinde etkisi firmaların faaliyet gösterdikleri endüstri ve firma büyüklügü için kontrol edilerek tahmin 
edilmiştir. Model 4'de ise faaliyet gösterdikleri endüstri ve firma büyüklüğü kontrol değişkenlerin yanı sıra kaldıraç oranı da analize katılmıştır. Model 5 ve 6'da firmaya özgü kontrol değişkenlerine ek olarak pazar konsantrasyonu ve pazar sertifikasyon konsantrasyonu olmak üzere pazar faktörleri dikkate alınmıştır.

Tablo 5. Rassal etki modelleri

\begin{tabular}{|c|c|c|c|c|c|c|}
\hline Bağımlı Değiş̧ken & $\begin{array}{c}\text { Modell } \\
\text { Aktif } \\
\text { karlllik }\end{array}$ & $\begin{array}{c}\text { Model2 } \\
\text { Aktif } \\
\text { karlulık }\end{array}$ & $\begin{array}{c}\text { Model3 } \\
\text { Aktif } \\
\text { karlllik }\end{array}$ & $\begin{array}{c}\text { Model4 } \\
\text { Aktif } \\
\text { karlulık }\end{array}$ & $\begin{array}{c}\text { Model5 } \\
\text { Aktif } \\
\text { karlllik }\end{array}$ & $\begin{array}{c}\text { Model6 } \\
\text { Aktif } \\
\text { karlllik }\end{array}$ \\
\hline ISO 9001 & $\begin{array}{r}2,777 * * * \\
{[0,730]}\end{array}$ & $\begin{array}{r}2,293 * * * \\
{[0,741]}\end{array}$ & $\begin{array}{l}1,377 * \\
{[0,759]}\end{array}$ & $\begin{array}{r}1,780 * * * \\
{[0,665]}\end{array}$ & $\begin{array}{r}1,657 * * * \\
{[0,592]}\end{array}$ & $\begin{array}{r}1,744 * * * \\
{[0,591]}\end{array}$ \\
\hline Firma Büyüklü̆g̈u & & & $\begin{array}{r}1,164 * * * \\
{[0,259]}\end{array}$ & $\begin{array}{r}1,511 * * * \\
{[0,223]}\end{array}$ & $\begin{array}{r}1,418 * * * \\
{[0,230]}\end{array}$ & $\begin{array}{r}1,221 * * * \\
{[0,236]}\end{array}$ \\
\hline Kaldıraç Oranı & & & & $\begin{array}{r}-22,99 * * * \\
{[1,175]}\end{array}$ & $\begin{array}{r}-18,42^{* * * *} \\
{[1,086]}\end{array}$ & $\begin{array}{r}-18,86^{* * *} \\
{[1,090]}\end{array}$ \\
\hline Pazar konsantrasyonu & & & & & $\begin{array}{r}-2,33 \\
{[1,437]}\end{array}$ & $\begin{array}{r}-1,695 \\
{[1,447]}\end{array}$ \\
\hline Pazar sertifikasyon konsantrasyonu & & & & & & $\begin{array}{r}10,00 * * * \\
{[2,805]}\end{array}$ \\
\hline Endüstri kukla değişkenleri & Yok & Var & Var & Var & Var & Var \\
\hline Sabit & $\begin{array}{r}1,428 * * \\
{[0,661]}\end{array}$ & $\begin{array}{r}-1,946 \\
{[2,746]}\end{array}$ & $\begin{array}{r}-5,949 * * \\
{[2,824]}\end{array}$ & $\begin{array}{c}4,748^{*} \\
{[2,445]}\end{array}$ & $\begin{array}{r}5,419 * * * \\
{[1,589]}\end{array}$ & $\begin{array}{r}0,459 \\
{[2,107]}\end{array}$ \\
\hline Örneklem & 1,485 & 1,485 & 1,485 & 1,485 & 1,440 & 1,440 \\
\hline Firma Âdeti & 165 & 165 & 165 & 165 & 160 & 160 \\
\hline
\end{tabular}

\subsection{B2C-B2B iş modelinin ISO 9001 Sertifikasyonu-Finansal Performans İlişkisi üzerinde etkisi}

Çalışmaya konu olan firmaların \%54'ü işletmeden işletmeye ticaret yapan firmalar ve \%46'sı işletmeden tüketiciye ticaret yapan firmalardır. İşletmeden işletmeye ticaret yapan firmalar ve işletmeden tüketiciye ticaret yapan firmalarının ISO 9001 Sertifikasyonu aktif karlılık ilişkisini etkileyen gerek firmaya özgü faktörler gerek pazar faktörleri açısından farklılık gösterebileceği düşünülmektedir. Bu sebep ile işletmeden işletmeye ticaret yapan firmalar ve işletmeden tüketiciye ticaret yapan firmalarının farklı ana kütlelerden gelip gelmediği ortaya konmalıdır. $\mathrm{Bu}$ amaç doğrultusunda kat sayısal olmayan Mann-Whitney Sınamasına başvurulmuştur.

Mann-Whitney Sinamas1 sonucunda $\mathrm{P}\{\operatorname{roa}(\mathrm{B} 2 \mathrm{C}==0)=\operatorname{roa}(\mathrm{B} 2 \mathrm{C}==1)\}>0,05$ ise, iki ana kütle dağılımının merkezi konumları aynıdır sıfır hipotezi kabul edilir. Ancak $\mathrm{P}\{\operatorname{roa}(\mathrm{B} 2 \mathrm{C}==0)$ $>\operatorname{roa}(\mathrm{B} 2 \mathrm{C}==1)\}<0,05$ ise, ön sav reddedilir (Newbold, 2000a). Tablo 6'te görülebileceği gibi 
üzere $(\mathrm{P}\{\operatorname{roa}(\mathrm{B} 2 \mathrm{C}==0)>\operatorname{roa}(\mathrm{B} 2 \mathrm{C}==1)\}=0,0163<0,05$ olarak gözlenmiştir ve sıfır hipotezi reddedilmiştir. Mann-Whitney Sınaması ile işletmeden işletmeye ticaret yapan firmalar $(\mathrm{B} 2 \mathrm{C}=0)$ ve işletmeden tüketiciye ticaret yapan firmalar $(\mathrm{B} 2 \mathrm{C}=1)$ için, aktif karlılık ana kütle dağılımlarının merkezi konumlarının farklı olduğu sonucuna ulaşılmaktadır.

Ayrıca Tablo 6'da görüleceği üzere işletmeden işletmeye ticaret yapan firmaların aktif karlılıklarının işletmeden tüketiciye ticaret yapan firmaların aktif karlılıklarından daha yüksek olma ihtimali \%53,6'dır. Bu bulgular işletmeden işletmeye ticaret yapan firmalar ve işletmeden tüketiciye ticaret yapan firmalar için analizlerin ayrı ayrı yapılması gerektiğine işaret etmektedir.

Tablo 6. Mann-Whitney Sınaması Sonuçları

\begin{tabular}{|c|c|c|c|}
\hline$B 2 C$ & Örneklem & Stra numaralarının toplamı & Beklenen \\
\hline 0 & 802 & 615675,5 & 595886 \\
\hline 1 & 683 & 487679,5 & 507469 \\
\hline Karma & 1485 & 1103355 & 1103355 \\
\hline \multicolumn{4}{|c|}{ düzeltilmemiş varyans 67831690} \\
\hline \multicolumn{4}{|c|}{\begin{tabular}{ll} 
düzeltme & $-21979,467$ \\
\cline { 2 - 2 }
\end{tabular}} \\
\hline \multicolumn{4}{|c|}{ düzeltilmiş varyans } \\
\hline \multicolumn{4}{|c|}{$H o: \operatorname{roa}(\mathrm{B} 2 \mathrm{C}=0)=\operatorname{roa}(\mathrm{B} 2 \mathrm{C}=1)$} \\
\hline \multicolumn{4}{|c|}{$z=2,403$} \\
\hline \multicolumn{4}{|c|}{ Prob $>|z|=0,0163$} \\
\hline \multicolumn{4}{|c|}{$\mathrm{P}\{\operatorname{roa}(\mathrm{B} 2 \mathrm{C}=0)>\operatorname{roa}(\mathrm{B} 2 \mathrm{C}=1)\}=0,536$} \\
\hline
\end{tabular}

Tablo 7'te sunulan tüm modellerde bağımlı değişken finansal performansın göstergesi olan aktif karlılık değeri iken bağımsız değişken ISO 9001 sertifikasına sahip olmasıdır. ISO 9001 sertifikasına sahip olma ISO 9001 kukla değişkeni ile temsil edilmiştir. Her iki modelde de firmaların faaliyet gösterdikleri endüstri, firma büyüklüğü, kaldıraç oranı, pazar konsantrasyonu ve pazar sertifikasyon konsantrasyonu kontrol değişkenlerin da analize katılmıştır. Model 7'de sadece işletmeden tüketiciye ticaret yapan firmalar örneklem olarak ele alınırken, Model 8'de ise sadece işletmeden işletmeye ticaret yapan firmalar dikkate alınmıştır. Hem Model 7'de hem de Model 8'de firmaya özgü faktörlerin Tablo 5'de elde edilen sonuçlara paralel olduğu gözlemlenmiştir. ISO 9001 sertifikasyonunun aktif karlılık üzerinde olumlu etkisi olduğu saptanmıştır, ayrıca firma büyüklüğünün olumlu kaldıraç oranının ise olumsuz etkisi gözlemlenmiştir. İşletmeden tüketiciye ticaret yapan firmalar için ISO 9001 belgesine sahip olan firmalar bu belgeye sahip olmayan firmalara kıyasla \%1,754 daha yüksek aktif karlılık elde etmektedirler. Benzer bir şekilde işletmeden işletmeye ticaret yapan firmalar için 
ISO 9001 belgesine sahip olan firmalar bu belgeye sahip olmayan firmalara kıyasla \%1,818 daha yüksek aktif karlılık elde etmektedirler.

Tablo 7. B2C-B2B iş modelinin ISO 9001 sertifikasyonu-finansal performans ilişkisi

\begin{tabular}{|c|c|c|}
\hline Băğmlı Değişken & $\begin{array}{c}\text { Model7 } \\
\text { Aktif karlılık }\end{array}$ & $\begin{array}{c}\text { Model8 } \\
\text { Aktif karlılık }\end{array}$ \\
\hline ISO 9001 & $1,754 * *$ & $1,818 * *$ \\
\hline \multirow[t]{2}{*}{ Firma Büyüklüğ̈̈ } & $\begin{array}{c}{[0,823]} \\
1,435^{* * *}\end{array}$ & $\begin{array}{c}{[0,832]} \\
1,206 * * *\end{array}$ \\
\hline & {$[0,356]$} & {$[0,330]$} \\
\hline \multirow{2}{*}{ Kaldıraç Oranı } & $-17,49 * * *$ & $-19,07 * * *$ \\
\hline & {$[1,718]$} & {$[1,398]$} \\
\hline \multirow[t]{2}{*}{ Pazar konsantrasyonu } & $-6,484 * *$ & $-0,188$ \\
\hline & {$[2,754]$} & {$[1,678]$} \\
\hline \multirow[t]{2}{*}{ Pazar sertifikasyon konsantrasyonu } & 0,36 & $14,42 * * *$ \\
\hline & {$[4,490]$} & {$[3,707]$} \\
\hline Endüstri kukla değişkenleri & Var & Var \\
\hline \multirow[t]{2}{*}{ Sabit } & 4,413 & $-2,018$ \\
\hline & {$[3,448]$} & {$[2,675]$} \\
\hline Örneklem & 638 & 802 \\
\hline Firma Âdeti & 71 & 90 \\
\hline \multicolumn{3}{|c|}{ Dirençli standart hatalar parantez içinde verilmiştir } \\
\hline
\end{tabular}

$\mathrm{Bu}$ analizde elde edilen ilginç sonuç ise Pazar konsantrasyonunun ISO 9001 aktif karlılık ilişkisinde işletmeden tüketiciye ticaret yapan firmalar için olumsuz etkisi var iken, işletmeden işletmeye ticaret yapan firmalar için belirgin bir etkisi olmamasıdır. Öte yandan pazar sertifikasyon konsantrasyonunun ISO 9001 aktif karlılık ilişkisinde işletmeden tüketiciye ticaret yapan firmalar için belirgin bir etkisi yok iken, işletmeden işletmeye ticaret yapan firmalar için olumlu bir etkisi vardır.

İşletmeden tüketiciye ticaret yapan firmalar için sektörlerinde mevcut bulunan rakip firma sayısı ISO 9001 aktif karlılık ilişkisini olumsuz etkilemektedir, yani rekabetin incelediğimiz ilişki üzerinde olumsuz etkisi olduğu söylenebilir. İşletmeden işletmeye ticaret yapan firmalar için sektörlerinde mevcut bulunan firma sayısının belirgin bir etkisi yok iken sektörde ISO 9001 belgesine sahip olan firma sayısının incelediğimiz ilişki üzerinde olumlu etkisi olduğu gözlemlenmiştir. Bir sektörde ISO 9001 belgesine sahip olma norm haline gelmişse bu 
sektördeki firmaların ISO belgesine sahip olmaları aktif karlılıkları üzerinde daha olumlu bir etkiye neden olmaktadır.

\subsection{Tedarik Zinciri Kademesinin ISO 9001 Sertifikasyonu-Finansal Performans İlişkisi üzerinde etkisi}

Çalışmaya konu olan firmaların \%44,4'ü OEM firmaları (orijinal ürün üreticisi) ve \%25 Tier-1 tedarikçi (anahtar üretici / bölgesel tedarikçi), \%25 Tier-2 tedarikçi (yerel tedarikçi/emtia üreticisi) ve \%5,62 Tier-3 tedarikçidir (hammadde tedarikçisi). Firmaların tedarik zincirine eklemlendikleri kademenin ISO 9001 Sertifikasyonu aktif karlılık ilişkisini etkileyen gerek firmaya özgü faktörler gerek pazar faktörleri açısından farklılık gösterebileceği düşünülmektedir. $\mathrm{Bu}$ sebep ile tedarik zincirinin farklı kademelerinde faaliyet gösteren firmalarının farklı ana kütlelerden gelip gelmediği ortaya konmalıdır.

Örneklemin arkasında iki den fazla ana kütle yattığından kuşkulanıldığında katsayısal olmayan Kruskal-Wallis Sınamasına başvurulur. Kruskal-Wallis Sınaması da Mann-Whitney sınaması gibi örneklem gözlemlerinin sıra numaralarına dayanır ve sınanacak sıfır hipotezi, dört anakütle ortalamasının aynı olduğunu söyler.

Tablo 8'den anlaşılacağ öbek olduğuna göre \%0,5 düzeyinde x 3,00052=12,84 olur. Bu durumda dört anakütlede roa ortalamaları aynıdır diyen sıfır hipotezi \%0,5 anlamlılık düzeyinde bile açıkça reddedilir (Newbold, 2000b). Tedarik zinciri kademesi gruplarının sıralamalar ortalamaları arasındaki fark istatistiksel olarak anlamlı bulunmuştur

Tablo 8. Kruskal-Wallis Sınaması Sonuçları

\begin{tabular}{|l|c|r|}
\hline & Örneklem & $\begin{array}{c}\text { Sira numaralarinın } \\
\text { toplamı }\end{array}$ \\
\hline OEM & 675 & 485887.00 \\
\hline Tier-1 & 369 & 269998.00 \\
\hline Tier-2 & 360 & 273193.50 \\
\hline Tier-3 & 81 & 74276.50 \\
\hline \multicolumn{2}{|c|}{ chi $^{2}=16,054(3$ serbestlik dereceli) } \\
\hline \multicolumn{2}{|c}{$\mathrm{p}=0,0011$} \\
\hline
\end{tabular}

Tablo 9'da sunulan tüm modellerde bağımlı değişken finansal performansın göstergesi olan aktif karlılık değeri iken bağımsız değişken ISO 9001 sertifikasına sahip olmadır. ISO 9001 sertifikasına sahip olma ISO 9001 kukla değişkeni ile temsil edilmiştir. Her dört modelde de firmaların faaliyet gösterdikleri endüstri, firma büyüklüğ̈̈, kaldıraç oranı, pazar 
konsantrasyonu ve pazar sertifikasyon konsantrasyonu kontrol değişkenlerin da analize katılmıştır. Model 9'da sadece OEM firmaları örneklem olarak ele alınırken, Model 10' de sadece Tier-1 tedarikçi firmalar dikkate alınmıştır. Hem Model 11'de sadece Tier-2 tedarikçi firmalar dikkate alınmıştır. Model 12'de ise sadece Tier-3 tedarikçi firmalar dikkate alınmıştır.

Model 9, Model 11 ve Model 12'de firmaya özgü faktörlerin Tablo 5'de elde edilen sonuçlara paralel olduğu gözlemlenmiştir. ISO 9001 sertifikasyonunun aktif karlılık üzerinde olumlu etkisi olduğu saptanmıştır, ayrıca firma büyüklüğünün olumlu kaldıraç oranının ise olumsuz etkisi gözlemlenmiştir. OEM firmalar için ISO 9001 belgesine sahip olan firmalar bu belgeye sahip olmayan firmalara kıyasla \%1,603 daha yüksek aktif karlılık elde etmektedirler. Benzer bir şekilde Tier-2 tedarikçiler için ISO 9001 belgesine sahip olan firmalar bu belgeye sahip olmayan firmalara kıyasla \%3,537 daha yüksek aktif karlılık elde etmektedirler. Tier-3 tedarikçiler için ISO 9001 belgesine sahip olan firmalar bu belgeye sahip olmayan firmalara kıyasla \%17,08 daha yüksek aktif karlılık elde etmektedirler. OEM firmaları için pazar konsantrasyonunun ISO 9001 aktif karlılık ilişkisinde anlamlı olumsuz etki gözlenmişken sertifikasyon konsantrasyonunun ISO 9001 aktif karlılık ilişkisinde belirgin bir etkisi olmadığı saptanmıştır. Tier-2 ve Tier-3 tedarikçi firmalar için pazar konsantrasyonunun ISO 9001 aktif karlılık ilişkisinde etkisi olmadığı gözlenmişken sertifikasyon konsantrasyonunun ISO 9001 aktif karlılık ilişkisinde anlamlı olumlu ilişkisi olduğu saptanmıştır.

Model 10'da görülebileceği üzere Tier-1 tedarikçiler için ISO 9001 sertifikasyonunun aktif karlılık üzerinde anlamlı bir etkisi olmadığı gözlenmiştir. Bu abnormal gözlemin sebebi ise bu tedarik zinciri kademesinde her iki pazar faktörünün de etkili olmasından kaynaklanabilir. Tier1 tedarikçilerin hem OEM firmalarının etkileyen pazar faktörlerinden, hem de Tier-2 ve Tier-3 tedarikçileri etkileyen pazar faktörlerinden etkilendiği söylenebilir. Tier-1 tedarikçiler OEM firmaları gibi nihai tüketiciden gelen etkiler sebebi ile ürün pazarındaki rekabetten etkilendikleri gibi, Tier-2 ve Tier-3 tedarikçiler gibi OEM firmalardan gelen etkiler sebebi ile sertifikasyon pazarındaki rekabetten de etkilenmektedir. Bu farklı etkiler Tier-1 tedarikçilerin net bir strateji izlemelerini engellediği için sertifikasyonun finansal performans üzerindeki olumlu etkisi bu grup için gözlemlenmemiştir. 
Tablo 9. Tedarik Zinciri Kademesinin ISO 9001 Sertifikasyonu-Finansal Performans İlişkisi üzerindeki etkisi

\begin{tabular}{|c|c|c|c|c|}
\hline Bă̆ımlı Değişken & $\begin{array}{c}\text { Model9 } \\
\text { Aktif karlılık }\end{array}$ & $\begin{array}{c}\text { Modello } \\
\text { Aktif karlılık }\end{array}$ & $\begin{array}{c}\text { Modell1 } \\
\text { Aktif karlılık }\end{array}$ & $\begin{array}{c}\text { Model12 } \\
\text { Aktif karlılık }\end{array}$ \\
\hline ISO 9001 & $\begin{array}{r}1,603 * * \\
{[0,817]}\end{array}$ & $\begin{array}{r}-1,117 \\
{[1,405]}\end{array}$ & $\begin{array}{r}3,537 * * * \\
{[1,099]}\end{array}$ & $\begin{array}{r}17,08 * * * \\
{[5,468]}\end{array}$ \\
\hline Firma Büyüklüğg̈ & $\begin{array}{r}1,480 * * * \\
{[0,357]}\end{array}$ & $\begin{array}{r}0,666 \\
{[0,619]}\end{array}$ & $\begin{array}{r}1.539 * * * \\
{[0,483]}\end{array}$ & $\begin{array}{r}1,142 \\
{[0,962]}\end{array}$ \\
\hline Kaldıraç Oranı & $\begin{array}{r}-17,64 * * * \\
{[1,725]}\end{array}$ & $\begin{array}{r}-15,78 * * * \\
{[2,091]}\end{array}$ & $\begin{array}{r}-23,96 * * * \\
{[1,997]}\end{array}$ & $\begin{array}{r}-14,99 * * * \\
{[4,664]}\end{array}$ \\
\hline Pazar konsantrasyonu & $\begin{array}{r}-6,714 * * \\
{[2,748]}\end{array}$ & $\begin{array}{c}33,13^{*} \\
{[18,59]}\end{array}$ & $\begin{array}{r}-1,496 \\
{[1,628]}\end{array}$ & $\begin{array}{r}10,4 \\
{[15,85]}\end{array}$ \\
\hline Pazar sertifikasyon & & & & \\
\hline konsantrasyonu & $\begin{array}{r}1,712 \\
{[4,441]}\end{array}$ & $\begin{array}{r}18,05 * * * \\
{[6,291]}\end{array}$ & $\begin{array}{r}12,14 * * \\
{[5,091]}\end{array}$ & $\begin{array}{r}19,76 * * \\
{[9,590]}\end{array}$ \\
\hline $\begin{array}{l}\text { Endüstri kukla değişkenleri } \\
\text { Sabit }\end{array}$ & $\begin{array}{l}\text { Var } \\
3,476 \\
{[3,442]}\end{array}$ & $\begin{array}{l}\text { Var } \\
\quad-1,398 \\
{[4,350]}\end{array}$ & $\begin{array}{l}\text { Var } \\
-2,889 \\
{[3,690]}\end{array}$ & Var \\
\hline Örneklem & 639 & 360 & 360 & 81 \\
\hline Firma Âdeti & 71 & 40 & 40 & 9 \\
\hline
\end{tabular}

Dirençli standart hatalar parantez içinde verilmiştir $* * * \mathrm{p}<0,01, * * \mathrm{p}<0,05, * \mathrm{p}<0,1$

\section{Değerlendirme ve Sonuç}

Bu çalışma ile Türkiye gibi gelişmekte olan bir ülkede İstanbul Menkul Kıymetler BorsasıBorsa İstanbul (BIST)'a kote olmuş üretim firmalarının 2010-2018 yılları arasında incelenerek ISO 9001 Kalite yönetim uygulamasının finansal performansa etkisinin incelenmesi hedeflenmiştir. Çalışma kapsamında panel veri analizleri Hausman testi uygulanması sonucunda rassal etki modeline göre yapılmıştır. İleriye doğru seçim yöntemi ile her defasında bir bağımsız değişken ilave edilerek tam modele ulaşılmıştır. Tam modelde ISO 9001 belgesinin aktif karlılık üzerindeki etkisi faaliyet gösterilen endüstri, firma büyüklügü, kaldıraç oranı, pazar konsantrasyonu ve pazar sertifikasyon konsantrasyonu değişkenlerinin analize katılması ile ortaya konmuştur. Analiz sonucunda ISO 9001 belgesinin aktif karlılık üzerinde anlamlı olumlu etkisi olduğu saptanmıştır. Ayrıca firma büyüklüğünün analiz edilen ilişki üzerinde anlamlı olumlu, kaldıraç oranın da anlamlı olumsuz ilişkisi olduğu gözlemlenmiştir. Pazar sertifikasyon konsantrasyonunun anlamlı olumlu etkisi gözlemlenirken pazar konsantrasyonunu anlamlı bir etkisi gözlemlenmemiştir. Tüm gözlemlerler beklenti dahilindeyken, klasik Endüstriyel organizasyon literatürün ortaya koyduğu pazar konsantrasyonunun anlamlı etkisinin (Motta, 2004) bu analizlerde gözlemlenmemiş olması, analizlerde kirletici bir etkenin dikkate alınmadığını göstermektedir. 
$\mathrm{Bu}$ kirletici etkinin firmaya özgü özelliklerden gelebileceği düşünülerek, örneklemdeki firmalar, işletmeden işletmeye ticaret yapan ve işletmeden tüketiciye ticaret yapan olmak üzere iki gruba ayrılarak bunların yüzdelik oranları hesaplanmıştır. Bu iki grubun farklı ana kütlelerden gelip gelmediğinin kontrolü için Mann-Whitney testi yapılmıştır. Yapılan test sonucunda işletmeden işletmeye ticaret yapan firmaların aktif karlılıklarının işletmeden tüketiciye ticaret yapan firmaların aktif karlılığından daha yüksek olma ihtimali \%53,6 olarak bulunmuştur. $\mathrm{Bu}$ nedenden dolayı iki grup için analizlerin ayrı ayrı yapılması gerektiği sonucuna varılmıştır. Her iki grup içinde ISO 9001 belgesine sahip olmak aktif karlılığa olumlu yönde etkilediği tespit edilmiştir. Bu kısımda iki grup arasında pazar konsantrasyonunun işletmeden tüketiciye ticaret yapan firmalara olumsuz etkisi ve pazar sertifikasyon konsantrasyonunun işletmeden işletmeye ticaret yapan firmalara olumlu etkileri gibi bazı farklılıklarda tespit edilmiştir.

$\mathrm{Bu}$ analizler ışı̆̆ında tedarik zinciri kademesinin etkisine daha detaylı bakılması gerekliliği ortaya çıkmıştır. Çalışmaya konu olan firmalar OEM, Tier-1 tedarikçi, Tier-2 tedarikçi ve Tier3 tedarikçi olmak üzere gruplandırılmıştır. Bu dört grubun farklı ana kütlelerden gelip gelmediğinin kontrolü için Kruskal-Wallis testi yapılmıştır. Yapılan test sonucunda dört grup için analizlerin ayrı ayrı yapılması gerektiği sonucuna varılmıştır. OEM, Tier-2 ve Tier-3 firmalar için yapılan analiz sonuçları işletmeden işletmeye ve işletmeden tüketiciye üretim firmalar için yapılan analiz sonuçlarıyla benzerlikler göstermektedir. Ancak Tier-1 tedarikçi firmalarda ISO 9001 belgesinin olması aktif karlılık üzerine bir etkisi olmadığı tespit edilmiştir. Bunun nedeni hem pazar konsantrasyonunun hem de ISO 9001 belgesine sahip olma gibi faktörlerin beraber etkili olması olarak gösterilebilir.

Bu gözlem Tier-1 işletmeler için risk oluşturduğu gibi firsatlar da doğurabilir. Eğer Tier-1 tedarikçi ürün pazarında oluşan tüketiciden gelen etkileri iyi yönetebilir ise, bu durumu avantaja çevirebilir. Örnek olarak bilgisayar üreticilerinin tedarikçileri kendi marka değerlerini kabul ettirerek Intel Core inside veya Radeon Graphics simgelerin nihai ürünlerin üzerinde olmasını sağlamışlardır. Bu strateji ile tedarikçi firma olmalarına karşı tüketici ile birebir bir ilişki kurarak rekabet avantajı sağlamışlardır. Türk tedarikçileri de benzer stratejiler geliştirebilirler.

Bu çalışmada ISO 9001 belgesinin firmaların finansal performansına etkisi incelenmiştir. Bu ilişkiyi etkileyecek firmaya özgü özellikler ve pazar faktörleri dikkate alınmıştır. Bu ilişki incelenirken pazar faktörlerinin ürün pazarındaki rekabet ve sertifikasyon pazarındaki rekabet olmak üzere iki katmanlı ele alınması ve firmaların tedarik zinciri kademesine göre ayrı gruplar halinde analiz edilmesi literatürde yeni bir bakış açısı getirmektedir. Bu yönüyle çalışmanın literatüre önemli katkılar sağlayacağı düşünülmektedir. 
$\mathrm{Bu}$ araştırmanın en önemli kısıtı veri setinin 2010-2018 yılları için BIST'de kote imalat firmalarından oluşturulmuş olmasıdır. İleriki çalışmalarda gözlem süresinin artırılması, KOBİ'lerin incelenmesi ve toplam kalite yönetimi uygulamaları ve sertifikasyonun önemli yere sahip olduğu sağlık, eğitim ve turizm gibi hizmet sektöründe de uygulanması yerinde olacaktır. Ayrıca literatürde firmaların ISO 9001 sertifikasyonu aldıktan önce sonra ki finansal performansının karşılaştırıldığı pek çok çalışma vardır. İleride bu araştırmayı genişletmek için daha fazla sayıda firmadan veriler elde edilerek finansal performansı etkileyen faktörlerin de sayısını çoğaltarak değişik yöntemlerle analizler yapılması bu alandaki yapılan literatür çalışmalarına katkı sağlayacaktır.

Yapılan Yeşil Mutabakat ile 2050 yılına kadar Avrupa kıtasını iklim nötr hale getirmek için firmaların karbon nötr olmaları ve döngüsel ekonomi prensiplerine uyum sağlamaları beklenmektedir. Gerek işletmeden işletmeye gerek işletmeden tüketiciye ticaret yapan Türk firmalarının Avrupa pazarı başta olmak üzere küresel pazarda rekabet edebilmeleri için ISO 140001 Çevre Yönetim Sistemi ve ISO 50000 Enerji Yönetim Sistemi gibi sertifikasyonları almaları önem kazanacaktır. İleride Türk firmaları için bu belgelerin performansları üzerindeki etkilerini inceleyen benzer çalışmaların yapılmasını faydalı olacaktır. 
Durak Uşar, D., Aylak, B. L., Kayıkc1, Y. / Journal of Yasar University, 2021, 16/63, 1454-1479

\section{KAYNAKÇA}

Aba, E. K., Badar, M. A., Hayden, M. Allen. (2016). Impact of ISO 9001 certification on firms financial operating performance. Int J Qual \& Reliability Mgmt 33 (1), 78-89. DOI: 10.1108/IJQRM-02-2014-0021.

Adıgüzel, O. ve Aydınlı, C. (2016). ISO 9001 Kalite Yönetim Sisteminin Bilişim Sektöründe Faaliyet Gösteren Firmaların İşletme Performansı Üzerine Etkileri: Ankara İli Örneği. Kastamonu Üniversitesi İktisadi ve Ídari Bilimler Fakültesi Dergisi, 12, 365-383.

Alpar, R. (2003) Uygulamalı Çok Değişkenli İstatistiksel Yöntemlere Giriş 1. 2. Baskı, Nobel Basımevi, Ankara Aslanertik, E. ve Tabak, B.İ. (2006). Marketing and Cost Dimensions of ISO 90001 Implementations of Small and Medium Sized Manufacturers: A Case Analysis. Ege Akademik Bakış Dergisi, 6(2), 47-57.

Aslan, E., İlkay, M. S., Özdemir, A. İ. (2009). ISO 9001 Belgeli KOBĐ’lerin Performans Farklılıklarının Bazı Faktörler Bakımından Analizi. Dumlupınar Üniversitesi Sosyal Bilimler Dergisi, 25, 35-40.

Ayriçay, Y., Uğurlu, M., Yaşar Uğurlu, Ö. (2009). "Kalite Yönetim Uygulamalarının Finansal Performans Üzerine Etkisi: Ampirik Bir Analiz.” Muhasebe ve Finansman Dergisi (42): 169-80.

Baltagi, B.H. (2005): Econometric Analysis of Panel Data: Third Edition. Wiley Publishers, UK, pp.15-32.

Berman, S.L., Wicks, A. C., Kotha, S., Jones, T. M. (1999). Does Stakeholder Orientation Matter? The Relationship Between Stakeholder Management Models and Firm Financial Performance. Academy of Management Journal, 42 (5), 488-506.

Caligiuri, P. (2006). Developing global leaders. Human Resource Management Review, 16 (2), 219-228. DOI: 10.1016/j.hrmr.2006.03.009.

Chen, Y., Wu, L., Zhai, Q. (2019). Does ISO 9000 Certification Benefit Service Firms?. Sustainability, 11 (21), 5886. DOI: $10.3390 / \mathrm{su} 11215886$.

Corbett, C. J., Montes-Sancho, M. J., Kirsch, D. A. (2005). The Financial Impact of ISO 9000 Certification in the United States: An Empirical Analysis. Management Science 51 (7), 1046-1059. DOI: 10.1287/mnsc. 1040.0358 .

Corbett, Charles J. 2008. “Global Diffusion of ISO 9000 Certification through Supply Chains.” International Series in Operations Research and Management Science 119: 169-99.

Das, R. C. (2015). Handbook of Research on Globalization, Investment, and Growth-Implications of Confidence and Governance. IGI Global Advances in Finance, Accounting, and Economics, 2327-5677. https://books.google.com.tr/books?id=_IgfCgAAQBAJ.

Donaldson, T. ve Preston L. (1995). Stakeholder Theory of the Corporation Concepts Evidence and Implications. Academy of Management Review. 1995, 20(1), 65-91.

Douglas, A. ve Glen, D. (2000). Integrated management systems in small and medium enterprises, Total Quality Management, 11(4-6), 686-690, DOI:10.1080/09544120050008075.

Duman, F. (2018). ISO 9001 Kalite Yönetim Sisteminin Firma Performansı Üzerine Etkisi: Ampirik Literatür Taramas1. International Journal of Academic Value Studies (Javstudies JAVS) 4(22): 882-89.

Edwards, A.L. (1959) Edwards Personal Preferences Manual. London: The Psychological Corporation, S. 6.

Eroğlu, E. (2004). Küçük ve Orta Ölçekli işletmelerdeki Kalite Güvence Uygulamalarının Bütünsel İşletme Performansı Üzerine Etkilerinin İncelenmesi, Yönetim Dergisi:İstanbul Üniversitesi Işsletme Fakültesi Íşletme İktisadı Enstitüsü, 15(49):88-102.

Flynn, B. B., ve Flynn, E. J. (2005). Synergies between Supply Chain Management and Quality Management: Emerging Implications. International Journal of Production Research, 43(16): 3421-36.

Franceschini, F., Galetto, M., Mastrogiacomo,L. ve Viticchiè, L. (2008). Diffusion of ISO 9000 and ISO 14000 Certification in Italian Commodity Sectors. International Journal of Quality \& Reliability Management 25(5): 452-65.

Greene, W.H. (2011) Econometric Analysis, seventh Edition, Prentice Hall, New Jersey, 379-380.

Hausman, J. (1978) "Specification Tests in Econometrics", Econometrica, 46, 1251-72.

Heras, I., Casadesús, M., Dick, G. P.M. (2002). ISO 9000 certification and the bottom line: a comparative study of the profitability of Basque region companies. Managerial Auditing Journal, 17 (1/2), 72-78. DOI: $10.1108 / 02686900210412270$.

Heras-Saizarbitoria, I. (2011). Internalization of ISO 9000: an exploratory study. Industrial Management \& Data Systems. 111 ( 8-9), 1214-1237. DOI: 10.1108/02635571111170776.

İlkay, M. S. ve Aslan, E. (2006). IS0 9001: 2000 Kalite Yönetim Sisteminin Kayseri Bölgesindeki KOBİlerin Performanslarına Etkileri Üzerine Bir Araştırma. H.Ü. İktisadi ve İdari Bilimler Fakültesi Dergisi, 24(2): 67-83.

İlkay, M. ve Aslan, E. (2012). The effect of the ISO 9001 quality management system on the performance of SMEs. Int J Qual \& Reliability Mgmt 29 (7), 753-778. DOI: 10.1108/02656711211258517.

Javorcik, B. ve Sawada, N. (2018). The ISO 9000 certification: Little pain, big gain? European Economic Review, 105, 103-114. DOI: 10.1016/j.euroecorev.2018.03.005. 
Durak Uşar, D., Aylak, B. L., Kayıkc1, Y. / Journal of Yasar University, 2021, 16/63, 1454-1479

Kafetzopoulos, D. P., Psomas, E. L., Gotzamani, K. D. (2015). The impact of quality management systems on the performance of manufacturing firms. Int J Qual \& Reliability Mgmt 32 (4), 381-399. DOI: 10.1108/IJQRM-11-2013-0186.

Kutlu, S. ve Duran, C. (2010). Sanayi İşletmelerinde Toplam Kalite Yönetimi Ve ISO 9000 Uygulamalarının Performans Üzerine Etkisi. Dumlupınar Üniversitesi Sosyal Bilimler Dergisi, 28, 239-252.

Llach, J., Marimon, F., ve Bernardo, M. (2011). ISO 9001 Diffusion Analysis According to Activity Sectors. Industrial Management and Data Systems, 111(2): 298-316.

Martínez-Costa, M., Martínez-Lorente, Á. R. (2007). A triple analysis of ISO 9000 effects on company performance. Int J Productivity \& Perf Mgmt 56 (5/6), 484-499. DOI: 10.1108/17410400710757150.

Motta, M. 2004. Competition Policy: Theory and Practice.. 551-561., New York, USA : Cambridge University Press.

Newbold, P. (2000a). İşletme ve İktisat İçin İstatistik, Çev. Ümit Şenesen, Literatür Yayıncılık, İstanbul, $442-447$

Newbold, P. (2000b). İşletme ve İktisat İçin İstatistik, Çev. Ümit Şenesen, Literatür Yayıncılık, İstanbul, 684-686.

Özbuğday, F. C., Tiğril, A. (2020). Kalite yönetim Sistemi Belgelendirmesi ve Satışlar: Türkiye'deki İmalat Firmaları için Bir Analiz. Finans Politik\& Ekonomik Yorumlar, 651, 45-57.

Özer, E. ve Karabulut, T. (2017). Kalite Uygulamalarının İşletme Performansı Üzerindeki Etkisi: İnşaat Sektöründe Bir Uygulama. İstanbul Ticaret Üniversitesi Sosyal Bilimler Dergisi, 16(31), 329-346.

Romano, P. (2000). ISO 9000: What is its Impact on Performance? Quality Management Journal 7 (3), 38-56. DOI: 10.1080/10686967.2000.11918905

Santos, G., Mendes, F., Barbosa, J. (2011): Certification and integration of management systems: the experience of Portuguese small and medium enterprises. Journal of Cleaner Production 19 (17-18), 1965-1974. DOI: $10.1016 /$ j.jclepro.2011.06.017.

Sea-Jin C., van Witteloostuijn, A., Eden, L. (2010): From the Editors: Common method variance in international business research. J Int Bus Stud 41 (2), 178-184. DOI: 10.1057/jibs.2009.88.

Sedani, C. M. ve Lakhe, R. R. (2009). 2nd International Conference on Emerging Trends in Engineering and Technology (ICETET), 2009. 16 - 18 Dec. 2009, Nagpur, India. Piscataway, NJ: IEEE. Available online at https://www.computer.org/csdl/proceedings/icetet/2009/3884/00/index.html.

Sharma, D. S. (2005). The association between ISO 9000 certification and financial performance. The International Journal of Accounting 40 (2), 151-172. DOI: 10.1016/j.intacc.2005.01.011.

Su, H. C., Kao,T.W. ve Linderman, K. (2020). Where in the Supply Chain Network Does ISO 9001 Improve Firm Productivity?. European Journal of Operational Research, 283(2): 530-40.

Terziovski, M., Power, D., Sohal, A. S. (2003). The longitudinal effects of the ISO 9000 certification process on business performance. European Journal of Operational Research. 146 (3), 580-595. DOI: 10.1016/S0377-2217(02)00252-7.

Turgut, O. (2014). Entelektüel Sermaye Üzerinde Kalite Yönetim Sistemi Uygulamasının Finansal Etkisi Borsa İstanbul (Bist)'a Kote Olan Şirketler Üzerinde Bir Uygulama. Suleyman Demirel University The Journal of Visionary, 62-94.

Wernerfelt, B. (1984) A resource- based view of the firm. Strategic Management Journal, 5(2), 179-191.

Yıldız, B., Aytekin, M. (2019). Kalite Yönetimi Uygulamalarının Firma Performansı Üzerindeki Etkisinde İnovasyonun Aracı Rolü ile Çevresel Dinamizmin Moderatör Rolü / The Mediating Role of Innovation and The Moderating Role of Environmental Dynamism on The Impact of TQM Applications On Firm Performance. Journal of Yasar University, 14(56), 489-506.

Zwanziger, J., Melnick, G.A. ve Simonson, L. (1996) Differentiation and Specialization in the California Hospital Industry 1983 to 1988 . Medical Care 34 (4), 361-372 https://www.jstor.org/stable/3766483. 